\title{
From Authoritarianism to Advocacy: Lifestyle-Driven, Socially-Transmitted Conditions Require a Transformation in Medical Training and Practice
}

\author{
Susan L. Prescott 1,2,* and Alan C. Logan 2 (D) \\ 1 Professor of Paediatrics, School of Medicine, University of Western Australia, PO Box D184, Princess \\ Margaret Hospital, Perth, Director, ORIGINS Project, Telethon Kids Institute, Perth, WA 6001, Australia \\ 2 Senior Fellow, in-FLAME Global Initiative, Research Group of the Worldwide Universities Network (WUN), \\ 6010 Park Ave, Suite \#4081, West New York, NJ 07093-9992, USA; aclnd@cfs-fm.org \\ * Correspondence: susan.prescott@uwa.edu.au or Susan.Prescott@telethonkids.org.au; Tel.: +61-89489-7777
}

Received: 29 January 2018; Accepted: 5 March 2018; Published: 8 March 2018

check for updates

\begin{abstract}
The epidemic of socially-rooted, lifestyle-driven non-communicable diseases (NCDs; also referred to as socially-transmitted conditions) has now overtaken infectious diseases as the leading cause of human mortality. Despite this reality, physician education, training and practice within industrialized nations is heavily slanted toward the biopharmaceutical (and away from the psychosocial) aspects of prevention and treatment. As we underscore, the current state of physician training and practical application of guidelines pertaining to lifestyle is paltry and untenable. However, the solution is not a few more hours of nutritional biochemistry to check off the curricula box. Physician readiness for the current NCD crisis will require a philosophical shift in medicine-at-large, including candidate pooling. Recent elections in the United States and Europe have cast a spotlight on the public health consequences of political authoritarianism. However, we highlight that authoritarianism - and its related facets of social dominance orientation and Machiavellianism-are not exclusive to political candidates. Here, we open a dialogue on authoritarianism in westernized medicine as a starting point in order to encourage the development of critical research and to explore its potential as a barrier to patient care. We suggest that authoritarianism and its prejudices act as a border wall to the World Health Organization's broad vision of global health, cultural competency and patient autonomy. Moreover, the evidence reviewed here would suggest that in the context of the NCDs crisis, westernized medicine is long overdue a Flexner Report for the 21st Century.
\end{abstract}

Keywords: authoritarianism; personalized medicine; social dominance; social justice; ecology; medical education; health policy; equity; holism; health translation; non-communicable diseases (NDCs); lifestyle medicine; shared decision making

\section{Introduction}

Chronic non-communicable diseases (NCDs) -including but not limited to diabetes, respiratory diseases, cardiovascular disease (CVD), cancer, mental disorders, neurological and musculoskeletal degenerative conditions-now represent the leading causes of disability and human morality. Indeed, the global spread of NCDs has been described as a pandemic [1]. Moreover, there are bi-directional relationships in co-morbidity; for example, depression may be a cause, effect, or both, in relation to 'physical' NCDs. The NCD-related costs to society from a purely economic vantage are so large that they are difficult to calculate.

Beyond the direct healthcare costs of specific diseases, NCDs are also interconnected, web-like, to countless variables ranging from workplace productivity to substance abuse and the use of prisons 
as primary mental health institutions [2-5] Certainly, the annual costs of diagnosable NCDs are in the trillions of dollars but these numbers belie the large numbers of individuals who experience subthreshold/subsyndromal depression and "low-grade" inflammation. These individuals are on a trajectory to one or more NCDs and in the meantime, in the here-and-now, are suffering nonetheless. They are far removed from the World Health Organization (WHO, Geneva, Switzerland) definition of health. Specifically, the WHO states that health is not the absence of specific disease criteria, non-communicable or otherwise but rather the fulfillment of human potential; it includes a state of complete physical, mental and social well-being [6].

To add to the seriousness of NCDs as one of the grand challenges of our time, research in animal models demonstrates that there are direct offspring and even trans-generational effects of environmental factors (e.g., prenatal stress, unhealthy diet, toxin exposure) transmitted to subsequent generations via germline cells [7-9]. The offspring and trans-generational fallout of environmental exposures appears to operate through epigenetic changes and can manifest in altered metabolism, heightened stress responses, immune dysregulation and microbiome disturbances [10,11]. Thus, the very term 'non-communicable' may be a misnomer insofar as neoliberalism and the societal policies and practices that influence 'exposures' (while blaming the individual [12]) are distributed throughout society and in turn, are 'shared' via the germline to next generations. Leading experts in the field are currently debating a phase out for the term NCDs, with socially transmitted conditions (STCs) recently proposed as a suitable replacement [13].

The World Health Organization (WHO, Geneva, Switzerland) Strategy for Global Health (2014-2023) underscores the benefits but also the limitations, of a strictly westernized biomedicine perspective. Rather, the strategy illuminates the total living environment of an individual, their cultural experiences/preferences and the inclusion of non-pharmaceutical forms of healing; these are part of a broader vision of improved health literacy and patient autonomy [14]. Furthermore, the WHO Montevideo Roadmap (2018-2030) on NCDs specifically includes a people-centered approach to prevention and palliative care and a greater investment in a healthcare workforce better equipped "to lead and implement actions to promote health and prevent and control NCDs" [15]. Moreover, in 2018 the WHO announced the formation of a Global High-level Commission on NCDs. While NCDs are often referred to as diseases of lifestyle 'choices,' the social and ecological factors which influence those choices and NCDs in general, are often overlooked [16-18].

In sum, while infectious disease remains a looming threat, the scale has now tipped toward NCDs as the primary health crisis of our time; given that NCDs are driven by complex social-lifestyle factors, it would be expected that medical education and clinical practice would be adapting accordingly. However, as we review here, there is enough available research to demonstrate that the evolution of westernized medical education remains, to some degree, stuck in a past paradigm; this Mid-(20th)-Century Modern model pays little, if any, attention to lifestyle and the total lived experience of the well and sick patient. Available evidence suggests that the voids in medical training/practice as they pertain to social causes/lifestyle factors and the presence of authoritarianism (and related 'isms'), are not disparate conversations in the Age of NCDs. Although WHO position papers are a wonderful compass to patient-centered care-implementation is the challenge.

\section{Roadmap to the Current Review}

Our primary argument is that the WHO goals of delivering culturally-sensitive, patient-centered care and promoting health literacy (in the context of prevention and treatment of NCDs) are impeded by two concomitant barriers. The first is lethargy concerning the high-level importance of patient lifestyle and social drivers as they manifest in the biology of individual in the waiting room. The second is the persistence of certain traits that linger within western medicine at the individual and institutional levels. These include the rarely discussed (in the context of medicine) traits of social dominance orientation, authoritarianism and Machiavellianism. Our fundamental argument necessitates discourse in and 
around many aspects of medical education/acculturation, psychology, medical sociology, the history of medicine, ecological medicine and inter-professional care.

Given the expanse of these fields and their interconnectivity, our commentary cannot be considered exhaustive. However, we hope to provide 'food for thought' among experts in various disciplines; in order to condense voluminous research, we have divided our commentary into four parts. Described below, these four parts illuminate an interconnectivity of seemingly disparate discussions. They also facilitate research questions which can be addressed my experts in various disciplines with an eye toward multidisciplinary collaboration.

Given that lifestyle-driven NCDs represent the lion's share of healthcare in modernity, we begin in Part I by examining the substructure upon which contemporary physicians are given a trusted societal position as experts in lifestyle approaches to health and disease. Patient-centered care, shared decision making, health advocacy and cultural competency are connected to the healing encounter, hence we approach our discussions from this perspective. As we will demonstrate, physician training, knowledge and preparedness for the lifestyle aspects of NCDs in westernized nations is paltry at best; physician as lifestyle 'expert' is a fallacy. Our larger concern here is with the maintenance of the fallacious idea that physicians, as currently trained, are lifestyle experts to be leaned on by society. We argue that the institutional preservation and promotion of such an idea-despite clear evidence to the contrary-s a hallmark of personality features that coalesce (from individual to organization) and prevent the meaningful changes sought by the WHO.

In order to segue to the ways in which aspects of the micro and macro-level psyche might prevent the aforementioned WHO goals, in Part II we introduce the historical influence of medical reformer Abraham Flexner and define authoritarianism, social dominance orientation and Machiavellianism-three significant aspects of personality-from the psychological perspective. We examine the available research on the extent to which they are present in medical trainees (and how medical training amplifies them), cluster in various medical specialties within the medical hierarchy and influence attributional style. Since these three traits appear to be non-randomly distributed in medical specialties, we argue that beyond specialties per se, individuals who hold these traits may also coalesce and influence institutional (e.g., professional, academic, internet-based) perspectives; although a minority at the individual level, the cohesion of these traits, by their very nature, promote the power dynamic of western medicine and any view that challenges the idea of physician as lifestyle authority represents a threat to this status.

In Part III we examine some of the criticisms of the ecological/psychosocial/lifestyle aspects of medicine-the idea that this is a soft science, unattractive to 'rigorous' scientific medicine, or where beneficial, much of its outcomes can be attributed to placebo and practitioner/patient belief systems. This is of relevance because, as we discuss, the rigidity of authoritarianism in medicine cannot accept approximations of clinical truths (that is, healing in the absence of perfectly identified biological pathways). Thus, a disdain for the placebo may be another related hallmark of medical authoritarianism; since many aspects of traditional medicine are presumed to operate through the placebo, the WHO Global Strategy of integrating diverse treatment approaches is considered a threat to elite status aspects of medicine that are "real." In this section, we provide the example of veteran mental health to illustrate how clinging rigidly to scientism and authoritarian traits is at odds, potentially fatal odds, with the WHO mandate for global health.

Finally, in Part IV we discuss possible future directions and many pressing research questions. Again, ours is a Commentary; the primary goal is to open up discourse which may seed ideas and creative research objectives by qualified experts. In this section, we argue that the reformation of medical education and preparedness for practice in the age of NCDs, massive socioeconomic inequalities, peak marketing of ultra-processed foods and gross environmental changes (climate change, biodiversity losses and urbanization) requires a Flexner Report 2.0. At this delicate time in human history, it can be argued that the need for trusted physician-patient-societal relationships has 
never been higher; pathways to investigate the relationships between medical education, medicine as a social institution and societal trust in the so-called post-truth era are explored.

At the outset, we underscore that medicine-with pharmaceutical advances, effective vaccines, surgical techniques and public health measures-has excelled in transforming human health for the better; physicians work to save life and limb and improve the quality of life of those with whom they engage. Countless are the examples of self-sacrifice and community service, both locally and globally, provided by physicians. Indeed, the research discussed below suggests that the traits in question-authoritarianism, social dominance orientation and Machiavellianism - are not found in most physicians in westernized nations. However, as we demonstrate, these aspects of personality appear to be uncomfortably prevalent, at least in westernized nations (our review largely encompasses North American, European and Australian research); given the dominance of westernized medicine, that's a problem for medicine-at-large, medical students, WHO goals and for patients with complex NCDs. Remaining silent on this topic, regardless of the NCD crisis, is unacceptable. When these traits show themselves at individual and institutional levels, the potential ripple throughout society warrants research and intellectual discourse.

\section{Part I}

\section{Patient-Centered Care, Sharing and Advocacy}

The Institute of Medicine defines patient-centered care as "care that is respectful of and responsive to individual patient preferences, needs and values and ensuring that patient values guide all clinical decisions" [19]. The term 'personal values' is oft-used but rarely defined; generally reflecting a variety of different attitudes, preferences and behaviors, which means that the physician must take steps to "get to know" the individual. As elegantly stated by Lilach Sagiv, et al. "understanding personal values means understanding human behavior" [20]. The idea that patient values guide all clinical decisions is understood to be bound by limitations-handling an acute trauma in the emergency room may not lend itself to understanding whether a patient's values include universalism or tradition. We will expand on discussions of these and other values later on.

Whether prevention or treatment, effective patient care is dependent upon the translation and application of evolving scientific knowledge. It is also dependent upon the manner in which the translation and application takes place. Shared decision making (SDM) describes the engagement of patients, a place where options and priorities are discussed and where patients are considered experts in how such options fit into their own lived experience (socioeconomic, cultural and otherwise). Despite emerging evidence demonstrating the effectiveness of SDM in outcomes involving NCDs [21,22], patients are rarely involved in decision making dialogue. For example, in one primary care study, physicians rarely discussed patient preferences, risks and benefits; specifically, $81 \%$ of clinical decisions did not elicit patient preference, $85 \%$ did not discuss alternatives and $91 \%$ did not discuss pros /cons. Moreover, even when verbal dietary and exercise recommendations were provided (only $6 \%$ and $5 \%$ of total clinical decisions, respectively), benefits and risks as a course of action were never discussed [23].

An upstream prerequisite to SDM and patient-centered care is cultural competency. Ideally this is an understanding of the patient's total lived experience, including their belief systems. However, such training is often restricted to ethnicity and race; less attention is paid to socioeconomic position, residential environment, gender, geographic origin, sexual preferences and various aspects of culture [24]. Although cultural competency training for medical professionals has been shown to help reduce provider bias and improve communication in limited research [25], the narrow focus on list-based 'characteristics,' which are presumed to be easily identified based on race/ethnicity alone, may perpetuate the very stereotypes which cultural awareness seeks to avoid [26]. Moreover, cultural competency often overlooks the fact that western biomedicine and its institutionalized delivery is a culture of its own, one that it is often assumed to be normative and just [27]; medical students are asked to learn about 'others' (often the minority) but not so much to reflect upon the cultural 'us' (biomedicine) and the privileged place from which that learning of 'others' takes place [28,29]. 
Despite the academic recognition that SDM is essential to patient-centered care in the age of NCDs, the reasons for lack of implementation (or even resistance to) SDM are far from elucidated [30]. Time constraints appear to be a legitimate blockade, which speaks to the larger ways in which western medicine experiences time crunch in both training and clinical practice. Interestingly, at least one study has shown that in the context of SDM, physicians consider the behavior of patients who search the Internet (to learn more about the experiences of other patients) to be 'annoying' - and especially annoying to physicians who maintain a paternalistic style [31]. We will return to personality shortly but for now will restrict our discourse to the idea that SDM (related to NCDs) requires knowledge and expertise concerning root causes and factors which maintain illness vis-à-vis the options, risks and benefits best suited for an individual and their preferences. Put simply, a prerequisite to SDM —on the part of the physician-is deep knowledge on matters of lifestyle.

In western nations, health advocacy is included as an important responsibility to be taught in medical training and adopted by the practicing physician [32,33]. For example, The Canadian (CanMEDS) Physician Competency Framework for medical training and practice states: "As Health Advocates, physicians contribute their expertise and influence as they work with communities or patient populations to improve health" [34]. However, in the context of medical education, adding statements on the importance of health advocacy is the easy part; implementing and assessing something that could be interpreted in many ways becomes more difficult [35]. In the above statement, "expertise and influence" are clearly potent words; how these words are put into practice will determine the future of health advocacy - will they emphasize health inequalities, the social determinants of health and an understanding that there are limitations to physician expertise in regard to the word health?

\section{Societal Trust, Medical Competencies}

Notwithstanding lay press stories with headlines such as "What you do not know about your doctor could hurt you" [36], physicians are among the most trusted members of western society [37]. As we underscored from the outset, the basis of physician trust-insofar as the diagnosis and treatment of disease via biomedicine-is hard-earned and well-deserved. Indeed, many physicians, especially those working outside academic centers, have long-term relationships with patients in the community [38].

While trust in physicians in general remains high, there has been a dramatic reduction (based on US surveys) in the public's confidence in the leaders of the institution of medicine-down from $66 \%$ in 1966 to $34 \%$ in 2012 [39]. This should be alarming if only because distrust might trickle downstream over time and erode the banks of trust in local physicians. Leaders of medical institutions are charged with ensuring a physician workforce fit for the practice of medicine in a shifting NCDs landscape; at the same time, they are also charged with protecting the 'turf of medicine' from encroachment by other health professionals. This can represent a quandary in the Age of NCDs. For example, medical institutions oppose pharmacists and nurse practitioners when they lobby for basic expansions in scope of practice- such as the ability to administer vaccines and prescribe various medications [40-42].

Meanwhile, practice expansion by pharmacists and nurse practitioners (when they finally do overcome opposition) has not led to widespread catastrophes and/or hospitals overrun by patients on gurneys as a result of allowing "unqualified" professionals to gain access to the tool box of medicine. Thus, with each passage of legislation allowing non-medical doctors to expand their practices and the passage of time proving their competency to do so (i.e., reducing the risk of NCDs [43]), the distrust of institutions who stood in opposition, grows. After all, pharmacists, nurse practitioners and other 'allied' health professionals are also public citizens with friends and family.

More specific to our discussion, however, is the way in which medical institutions oppose allied health professionals, the language used in political marketing campaigns and how that interferes with progress. Opposition to nurse practitioners and pharmacist prescribing medications or administering vaccines takes on an authoritarian tone. This is reinforced by the absence of training in medical schools which would otherwise temper the notion that the physician is exclusively the authority figure in 
team-based medicine. As stated by scholars Michael Wilkes (MD, PhD) and Robin Kennedy (PhD, MSW), concerning lack of progress with medical student training on inter-professional care:

"We have done little to help our trainees understand the role and approaches to care offered by other team members ... too often the model has been to teach our trainees leadership skills with the explicit and implicit assumptions that they will always be captains of the ship rather than just one important member of the crew" [44].

At the center of community engagement is the understanding that many different types of providers are engaged in the promotion of health and wellness in the community-at-large. This includes practitioners with distinct training and values which may place greater emphasis on tradition and care (and less on technology). The crisis and complexity of NCDs necessitates inter-professional care wherein professional skills sets are combined to provide the well-coordinated patient-centered care described above. Research shows that collaborative inter-professional care is well-suited to NCDs such as depression, cardiovascular disease, diabetes and cancer; in this context the WHO states that 'professional is an all-encompassing term that includes individuals with the knowledge and/or skills to contribute to the physical, mental and social well-being of a community' and that health workers includes 'professionals with discrete/unique areas of competence, whether regulated or non-regulated, conventional or complementary' [45]. Encouragingly, brief educational interventions can have positive effects and contribute to the development of health professionals who are ready to collaborate with others in order to improve patient outcomes [46]. Working together through immersion, even for brief periods during medical training, may help to temper hierarchical thinking among medical students.

Among westernized nations the practice of medicine requires a minimum of 3 years of medical school (e.g., McMaster University, Hamilton, ON, Canada) and two years of residency (Canada-wide, family medicine). There is little evidence to show that broadening this time in order to accommodate additional training and experience in technological and pharmacological aspects of clinical care actually leads to better patient outcomes [47]. Indeed, early research in medical sociology showed that academic performance during medical school or the status of a particular medical school is not correlated with better clinical performance later on in practice [48]. Admittedly, there are tremendous pressures on medical school administrators concerning the maintenance of essential, traditional, aspects of medical training vs. the incorporation or expansion of topics which otherwise receive little attention.

For decades, the medical humanities have called for expansion into curricula; the scientific justification to do so is on their side, especially with regard to history [49]. Others have called for expansion of hours devoted to statistics, epidemiology and critical appraisal of the research which guides practice [50]; the large-scale integration of the core concepts of evidence-based medicine over the last decade illustrates that change can happen, if the will is there [51]. However, while individual courses are added, the medical curriculum is stubbornly resistant to systemic changes; scholars have correctly pointed out that at least part of this resistance to change, especially with regard to physician as but one part of a larger healthcare team, is based on the hierarchical mindset set in motion by Abraham Flexner (discussed in more detail shortly) [44,52].

In addition to SDM, health advocacy and cultural competency, the stated goals of medical training in western nations includes the development of related skills and behaviors. These include physician self-reflection, respect, empathy, altruism, compassion, responsiveness to distress and an understanding of patient spirituality, beliefs and meaning. The physician should also understand the social and psychological factors which contribute to, or result from, the medical condition at hand $[53,54]$. In the Age of NCDs, the multi-factorial, socially-transmitted conditions, the importance of these skills cannot be overstated. Barriers to accruing and implementing these skills are blockades to WHO goals. 


\section{Lifestyle in Training and Practice}

Total time of medical school academics and residency is oft-discussed but should not be confused with preparedness for psychosocial and ecological aspects of care. For example, as many as $85 \%$ of graduating medical students in one North American study report being ill-prepared to engage in exercise counseling. Indeed, the vast majority of students reported no training on clinical interactions concerning exercise guidance [55]. Graduating medical students in the United Kingdom underestimate the role of physical activity in the global disease burden and many are unfamiliar with established guidelines [56]. Less than half of all medical school curricula throughout the United States provide any formal training on physical activity [57]. In Australia, instruction on physical activity in medical schools is also reported to be less than adequate; for most the total hours spent dedicated to physical activity is in the single digits and less than half provide instruction on strength training guidelines [58].

Nutrition education also remains paltry- $70 \%$ of medical schools in the USA fall short of even the lowest possible recommended bar of $25 \mathrm{~h}$ of nutrition education. Moreover, the bulk of nutrition instruction provided-when it is provided-is still confined to preclinical (e.g., biochemistry) contexts [59]. As important as that may be, recent surveys from European and Australian medical schools indicate that minimal attention is given to the clinical aspects of nutrition for NCDs [60]. Moreover, evidence suggests that average hours devoted to nutritional education are trending down in North American medical schools [61].

In a recent survey of North American cardiologists, $90 \%$ reported receiving no or minimal nutrition education during fellowship training, 59\% reported no nutrition education during internal medicine training and $31 \%$ reported receiving no nutrition education in medical school [62]. Consider the specialty of early-life care where multi-generational health is on the line-pediatrics. North American and international medical school graduates entering a US pediatric residency were found to be deficient in basic nutritional knowledge [63]. Among these physicians, the average percentage of correct answers (52\%) was only marginally different than patient groups who completed the same 18-question test $[64,65]$. Various studies have found similar holes in basic knowledge [66-69]. For example, although most medical students $(68 \%)$ in a recent study considered nutritional counseling to be important, more than half did not pass a basic nutrition test; questions about energy density, energy balance, cholesterol guidelines and medical nutrition therapy for aspects of metabolic syndrome were answered incorrectly [70]. Lack of accountability exists because only a tiny fraction of board/licensing questions are oriented toward detailed nutritional knowledge, especially in regard to chronic disease management and prevention [71].

Research also shows that only a small percentage of clinicians actively engage patients with specific and broad aspects of lifestyle guidance. For example, despite the unequivocal importance of physical activity, nutrition, smoking cessation and healthy weight management guidance during pregnancy — variables that obviously affect multi-generational health-research from North America and Australia shows that relatively few women receive lifestyle guidelines from physicians [72-74]. Discussions of physical activity in primary care and awareness of specific physical activity guidelines is very low [75]. Studies have shown that despite obesity prevalence and the obvious need for health education, approximately $60 \%$ of visits by obese patients involve a complete absence of physician engagement with lifestyle counseling/health education [76]; despite evidence showing that the adoption of a healthy lifestyle following a cancer diagnosis is linked with better long-term outcomes, the personal beliefs of physicians (that is, not believing lifestyle would affect outcomes) diminishes the likelihood of lifestyle counseling [77]. In age-related macular degeneration, specific guidelines have been crafted by the Royal College of Ophthalmologists concerning smoking cessation, as well as diet and nutritional supplement advice to be given to all patients. However, a recent post-visit study of patients shows that very few recommendations were made by physicians on these three matters [78].

Consider, also, the public's trust in physician knowledge concerning climate change and health. Clearly this trust is predicated on the perception that physicians are fully aware of (and in full agreement with) the global scientific consensus that climate change over the last century is a mostly 
human-generated phenomenon [79]. Furthermore, climate change will have numerous and profound health consequences, especially among disadvantaged communities whom will bear the initial brunt of its rapid progression [80]. However, much like presumed expertise in nutrition and exercise, the basis of trust cannot be squared with recent surveys of physicians specializing in allergy and lung function. Although the abstracts of these published surveys paint a rosy picture of physician alignment with scientific consensus on climate change, this belies the information contained in the responses. As many as $47 \%$ of physicians are at odds with scientific consensus by answering that climate change is either (a) not happening; (b) it is mostly a natural phenomenon; or (c) that human activity is no more of a factor than natural processes [81-83]. Furthermore, approximately $40 \%$ could not agree with the statements that "Physicians should have a significant advocacy role in relation to climate change and health" and "My medical societies should have a significant advocacy role in relation to climate change and health" and $50 \%$ could not agree with the statement "I feel that actions I take in my personal and/or professional life can contribute to effective action on climate change."

The sum of this information would suggest that there is a broad divide between the marketing of physician as trusted authority in matters of lifestyle as they pertain to health and the evidence which suggests otherwise. Moreover, it suggests that clinicians bring preformed opinions, political and otherwise, into treatment rooms. Indeed, the interpretation of scientific findings is molded to suit personal attitudes and worldviews. When scientific conclusions conflict with ideological stances, individuals-both conservative and liberal in political views-process evidence in ways that support their preferred conclusions; they may also deny the validity of findings when provided an interpretation that is inconsistent with their preferred conclusions [84]. If a physician believes that lifestyle and ecological concerns are down in the lower tiers of the practice 'hierarchy,' then it would be easy to see how SDM would be anything but shared.

\section{Part II}

\section{Flexner and Flexibility}

Thus far, we have underscored the unfulfilled potential of SDM and highlighted the significant voids in education, training and application of lifestyle/ecological factors pertaining to health promotion in the age of NCDs. Despite the obvious-if not urgent-need for change, medical recruitment and academic curriculum in westernized remains largely moored to its Flexnarian past. Much has been written on medical education transformer Abraham Flexner's famous Flexner Report on Medical Education in the United States and Canada, including the academic, hierarchical and authoritarian approaches to medical preparedness [85]. The Flexner Report of 1910 [86] gave western medicine a push onto its path to pharmaceutical innovation, laboratory standards and the contemporary science and surgery-based approaches to medical care. On this score, it has been immensely successful and the benefits to individuals and society are undeniable.

In fairness, Flexner did acknowledge that refinements in medical education with a focus on basic sciences and laboratory knowledge were far easier to establish and examine:

"The practitioner deals with facts of two categories. Chemistry, physics, biology enable him to apprehend one set; he needs a different apperceptive and appreciative apparatus to deal with other, more subtle elements. Specific preparation is in this direction much more difficult; one must rely for the requisite insight and sympathy on a varied and enlarging cultural experience."

He also showed insight, long before the NCDs epidemic, that the physician's role was shifting into prevention:

"The physician's function is fast becoming social and preventive rather than individual and curative. Upon him society relies to ascertain and through measures essentially educational to enforce, the conditions that prevent disease and make positively for physical and moral wellbeing." 
Thus, it would seem that Flexner cannot be held accountable for the way in which the report was subsequently co-opted in an almost exclusively biomedical direction [87]. Still, more than a few critics at the time referred to it as elitist and could see how the report's findings could potentially unfold. What would happen, Flexner's contemporaries asked, if the patient is reduced only to simple pathophysiology characterized by laboratory tests [88]? Actions taken upon Flexner's report subsequently catapulted the profession of medicine upward in the elite social ranks but within a short period of time, according to physician-scholar Julian Tudor Hart, "its new doctors needed no understanding of the anatomy or physiology of society, nor of the social history of medicine, for these might impede their acquisition of the limitless facts of medical science" [89]. Perhaps the academic disconnect from the social and ecological medicine was sustainable at a time when medicine was making tremendous strides for societal good, especially with regard to infectious diseases. But we argue that in the Age of NCDs, even though the physician of the future may increasingly deliver personalized medicine from accurate algorithms, the empathic physician will be increasingly prized.

Flexner's legacy is also that of the university-based teaching hospital; most often this has translated into teaching a biomedical-dominated paradigm in large, urban-based academic medical centers. Lost in the process is active community-based involvement and opportunities for improving health literacy in remote and disadvantaged communities (including those that may be in close proximity to medical centers). The absence of community involvement during medical training can amplify power inequities between academic institutions and communities and obscure the local social determinants of health [90]. Moreover, in the context of NCDs, hospital-based outpatient visits with rotating physicians diminishes the opportunity to build trust through repeated consultations over time; it is well known that patients often enter an out-patient visit with somatic complaints and are reluctant to broach the subject of anxiety, depressive symptoms and/or substance abuse. In short, the dominance of academic teaching hospitals disconnected from the community-at-large and their utilization as primary care centers may be compromising the psychosocial aspects of physician education.

There have been movements toward empathy and cultural competency training in medical schools but the extent to which these are merely 'check-off' boxes remains an open question. The crisis of NCDs has taught us that we must move upstream to the social 'causes of the causes' and, so too, with medicine there is a need to move upstream and examine how medical school recruitment and training selects and trains the best possible candidates, not only to serve the individual patient but society at large. This brings us to the oft-overlooked topic of authoritarianism in medicine.

\section{Authoritarianism in Medicine}

Authoritarianism (expecting or requiring people to obey; favoring a concentration of power; limitation of personal freedoms) generally is not the sort of attribute that is be celebrated in modern society. Research studies dating back to the 1950s have linked authoritarianism with broad aspects of prejudice, rigid adherence to mainstream convention and the stigmatization of out-groups [91-93]. The authoritarian uses broad brush strokes in a cognitive style devoid of depth and nuance; out-groups are branded in simplistic, all-or-none style [94]. Authoritarianism predicts an intolerance to diversity and differing cultures, aggression toward out-group members and hyper-vigilance to threats against non-conformism [95]. (see Box 1)

Recent elections in the United States and Europe have opened up much-needed discourse on the public health consequences of political authoritarianism [96,97]. The influence of political and institutional authoritarianism on healthcare delivery has been much-discussed in the context of social sciences; for example, differences in medical practice based on political regimes in certain nations and as a factor in socioeconomic inequalities in health have received considerable attention [98-100]. Some research has examined the popularity of traditional forms of medicine as a cultural response to authoritarian policies and practices (for example in the 1960s and 1970s), while others have examined the ways in which traditional, holistic forms of medicine are coerced into isolation via authoritarianism [101]. Moreover, the role of power and larger aspects of colonialism in the 
appropriation of indigenous (and traditional medical) knowledge-has been discussed in detail by experts in the fields of health sociology [102].

Box 1

Authoritarianism at the individual level is associated with rigid thinking, obedience to individuals and institutions perceived as powerful, desire for order and conformity, abuse of power and aggression toward those outside the circles of the dominant groups or institutions. As reviewed in detail by scholar John Duckitt, research shows that authoritarianism appears to be a relatively stable aspect of personality, although it can be influenced by social learning and culture; hence, authoritarianism can also be conceptualized through social attitudes and value dimensions [103].

Individuals who score higher on authoritarianism scales are more likely to devalue the importance of social factors in human health [104]. Studies which have specifically examined authoritarianism as a psychological trait in medical trainees and physicians in western nations have been conducted but have received very little attention. Research shows that about $20 \%$ of North American medical students score high on authoritarian scales [105] and authoritarianism increases through the years of medical training, especially in males [106,107]. To illustrate the lack of attention to this area, we can look to Joseph M. Merrill and colleagues study of authoritarianism in North American medical students [105]. This team used a large sample size from geographically distinct regions and since published in 1995 (thus, it was conducted 2 decades removed from the cultural revolution of the 1960s-1970s which is said to have challenged authoritarianism) it has only received 16 citations (as of January 2018) on Google Scholar.

Elitism in medicine is also connected to lowered empathy and higher levels of medical authoritarianism [108]. It refers to the belief that one is a member of a socially superior segment of society. To better appreciate what medical authoritarianism and medical elitism look like in research responses, it means greater agreement with statements such as: "Conscientious patients deserve better health care than those with self-inflicted conditions." "Those who contribute the most to society should get better health care" and "If certain groups of people stayed in their place, we would have fewer problems." It means greater disagreement with "We should do what we can to equalize conditions for different groups" [105,109]. Authoritarian predisposition is associated with lower scores on pro-diversity scales; that translates as greater disagreement with statements such as "It is easier to solve problems in a society with a high degree of cultural diversity" [95]. In a large sample of US medical students $(n=423)$, Merrill found that negative beliefs about patients with psychological problems increased through training but those with such (high) negative beliefs differed from their classmates in other ways; they also scored higher on authoritarianism scales and were more drawn to the high-tech aspects of medicine [110].

Closely related to authoritarianism and deficits in pro-diversity attitude is an individual's social dominance orientation (SDO); at the individual level, SDO is linked to attraction to hierarchy and prestige within social systems. SDO scales capture beliefs regarding social and economic inequality and attitudes toward the acceptability or entitlement of high-status groups to dominate other groups. Put simply, research shows that SDO generates prejudice and dampens the awareness that power gained from the dominant social position is being used for personal gains [111,112] —higher scores on SDO would typically translate as less concern for matters of social justice and inequalities. SDO also means hyper-vigilance to any threats to perceived benefits of privileged status. The potential ripple effect of individual SDO into society is described in Box 2.

\section{Box 2}

"Indeed, social dominance orientation robustly predicts the endorsement of hierarchy-enhancing and hierarchy-justifying intergroup attitudes such as racism, sexism and support for harsher criminal sentences for minority offenders and disapproval of hierarchy-attenuating ideologies and redistribution policies such as social welfare, civil rights and multiculturalism" [107] 
It should therefore be alarming that scores on SDO can be high among certain medical students as they enter school (associated with lower perspective taking/empathic attitudes) [113]; since SDO can be groomed by environmental context, or even provoked by status reminders and cues such as money $[114,115]$, it is far more concerning that SDO elevates through the course of medical training [116]. When researchers manipulate environmental conditions so as to increase perceptions of power, individuals with the highest baseline SDO scores show even further increases in SDO [117]. Moreover, it cannot be helpful that medical schools in developed countries continue to recruit from affluent applicants frequently disconnected from the disadvantaged out-groups so-often the victims of stigmatization and institutionalized inequity $[118,119]$. Again, authoritarianism and SDO are closely linked; they have been described as the "lethal union" because (combined) they can explain as much as $56 \%$ of the variance in generalized prejudice, while empathy is linked to lower generalized prejudice [120].

\section{Machiavellianism}

Authoritarianism and social dominance orientation have been linked together in personality and are both linked to generalized prejudice [121]; also linked to authoritarianism is the related personality trait of Machiavellianism. This describes an individual's potential to be detached from conventional morality while deceiving and manipulating others for a sort of end(s) which are perceived to justify means (which is often quite literally, behaviors that are 'mean') [122]. Scoring high on the Machiavellianism Scale translates as higher levels of cynical beliefs and lower levels of empathy, conscientiousness, agreeableness and trait emotional intelligence [123]; it is also associated with dispositional contempt, the tendency to look down on, distance and derogate others who violate preconceived standards [124] (Box 3). Importantly, for the Machiavellian, the manipulation of others is often an approach wherein the endgame is oriented toward the induction of shame, embarrassment and/or, or guilt in the target [125].

The developer of the scale, Richard Christie and colleague Robert K. Merton, found that medical students scored higher on Machiavellianism than other university students, business executives and remarkably, even registered Washington DC lobbyists [122]. Disturbingly, authoritarianism and Machiavellianism in medicine predicts negative attitudes toward those with chronic pain, substance abuse and unexplained symptoms [105]. The authoritarian (or Machiavellian) physician is more likely to place judgment on certain patients for making their own lifestyle choices; this, of course, compounds the similar but larger societal-scale neoliberal mantra which suggests personal responsibility is the sole path to health.

Previous North American research showed that about 15\% of medical students score uncomfortably high (from a societal perspective) in Machiavellianism [126] and as mentioned, Machiavellianism is strongly associated with authoritarianism. Medical specialties high in technology (low in personal interaction) have been reported to be a preferred destination for those scoring high on Machiavellianism and authoritarianism, while on the other hand, students destined for pediatrics, psychiatry and family medicine score low in Machiavellianism and authoritarianism [105,126]. Moreover, reliance upon high-technology has been reported to be a predictor of intolerance to uncertainty, authoritarianism and Machiavellianism in medical students; supporting the discussion above, these students were more likely to have negative attitudes toward patients with mental illness, chronic pain and medically-unexplained symptoms [127,128]. Intolerance to uncertainty, it is worth noting, has long-since been linked to authoritarianism, dogmatism and rigid thinking $[129,130]$.

One study from the United Kingdom, written in tongue-in-cheek style, claims that Machiavellianism scores among healthcare workers $(3 / 4$ sample $=$ physicians $)$ are lower than the general public. However, the recruitment of 'general population' was limited to snowball sampling (i.e., chain of acquaintances) via social media which contaminates the study with community bias; neither did it factor employment status, occupation (particularly important in Machiavellianism), education, income, race or any major socioeconomic indicators [130]. Hence, a meaningful study of 
medical Machiavellianism scores in relation to the general public, or the average patient in the waiting room, awaits.

Box 3

The Machiavellianism Scale (Mach IV) contains 20 items which cover three dimensions: (1) the use of deceit in
interpersonal relationships; (2) a cynical view of human nature and (3) the lack of morality. Higher
Machiavellianism is associated with manipulation of others, lower emotional intelligence, agreeableness
and conscientiousness.

In agreement with a potential Machiavellian overlap with attraction to prestige and dominance, a recent study by researchers from the Universite' Catholique de Louvain in Belgium and McGill University in Canada found that medical students destined for technical specialties (vs. family medicine, pediatrics, psychiatry) were more likely to score higher in SDO [116]. Moreover, studies have shown that medical specialty choice predicts empathy, with physicians in (or students destined for) pediatrics, family medicine and psychiatry scoring high in empathy $[131,132]$. Since perspective taking is a cardinal feature of emotional intelligence, it is not surprising that empathy and emotional intelligence are positively correlated in medical students [133]. We also point out that lower empathy scores predict higher levels of medical authoritarianism and elitism [108,113].

We will further discuss medical specialties and aspects of personality below; however, it is worth pointing out at this stage that the paradigm of the medical specialist, especially those involving a deeply technical approach, is one which addresses complicated problems that are responsive to specific solutions after diagnostic assessments. On the other hand, family medicine, psychiatry and pediatrics often address complex (distinct from complicated) psychosocially and ecologically-rooted problems that are responsive after trial-and-error (what might be called evidence-informed "research and development" at the $n=1$ ) approaches. While certain medical specialties are often considered technologically sophisticated, it is on the front lines of primary care that the clinician must deal with dynamic, non-linear complexity - where the whole is greater than the sum of its parts and simple solutions cannot be imposed [134]. Thus, it is interesting that medical students oriented toward primary care, pediatrics and psychiatry - 'specialties' of great complexity-would score lower in SDO and higher in empathy.

\section{Part III}

\section{Barriers, Authoritarianism and Suffering}

In looking at the current NCDs epidemic, it is clear that the biomedical paradigm is far removed from the psychosocial 'causes of the causes.' Although the placebo weaves its way throughout all branches of medicine, the authoritarian perspective suggests that it should be eliminated from anything which might be called 'medicine.' Successful outcomes are often driven by beliefs and expectations but westernized biomedicine is reluctant to point this out. As famed physician William Osler stated: "while we doctors often overlook or are ignorant of our own faith cures, we are a wee bit too sensitive about those performed outside our ranks" [135].

However, a recent editorial in the American Journal of Psychiatry (2017)—one which was not listed as an opinion piece-provides optimism for changing attitudes. The editorial asked what could be learned from placebo research and how could it be translated to clinic. The answers were presented in 4 unambiguous points:

1. Do not leave the patient uncertain about treatment effects.

2. Induce hope and optimism. Tell the patient that the treatment will work and the future will be fine.

3. Help the patient look for improvement and recognize positive changes, whether they are treatmentrelated or not.

4. Use suggestion to convey the optimistic message. Tell the patient how he or she should feel. 
The article concludes on placebo ethics, stating that it is actually ethical to ask one simple question-"whether it is allowed to let the patient suffer in the name of truth" [136]. The authoritarian in medicine may have great difficulty with the above-mentioned four points on placebo in practice, most notably the idea that telling the patient the treatment will work and using suggestion is acceptable. However, this discussion of the ethics of allowing suffering to take place-that is, maintenance of suffering in the name of scientific truth-especially in a premier medical journal, are, in our opinion, a salve to authoritarian outlooks.

The total environment matters in the physician-patient encounter, including things that are left unsaid. The collective non-verbal communication on the part of the physician-the total environment in which they perform - is collated by the patient; this information, including perceptions of empathy and warmth on the part of the physician, is used to evaluate perceived competency [137]. There is little doubt that perceptions of empathy, warmth and competency translate into positive health realities.

In their article on the cultivation of authoritarianism and Machiavellianism in medical students, the physicians and scientists from Baylor College of Medicine quote Nobel-Prize-winning philosopher Jean-Paul Sartre in his description of authoritarians. Sartre describes the authoritarian "as attracted to the rigidity of stone and unwilling to accept truth as an approximation" [105]. We proffer that Sartre's message cuts to the heart of the matter with regard to unrealized SDM, resistance to options/approaches preferred by patients and relegation of 'soft science' lifestyle factors in favor of biotechnical solutions to NCDs. Clinical truths will always be approximations in so far as the physiology and epigenetics of the person in the waiting room are influenced by complex ecosystems large and small (See Figure 1).

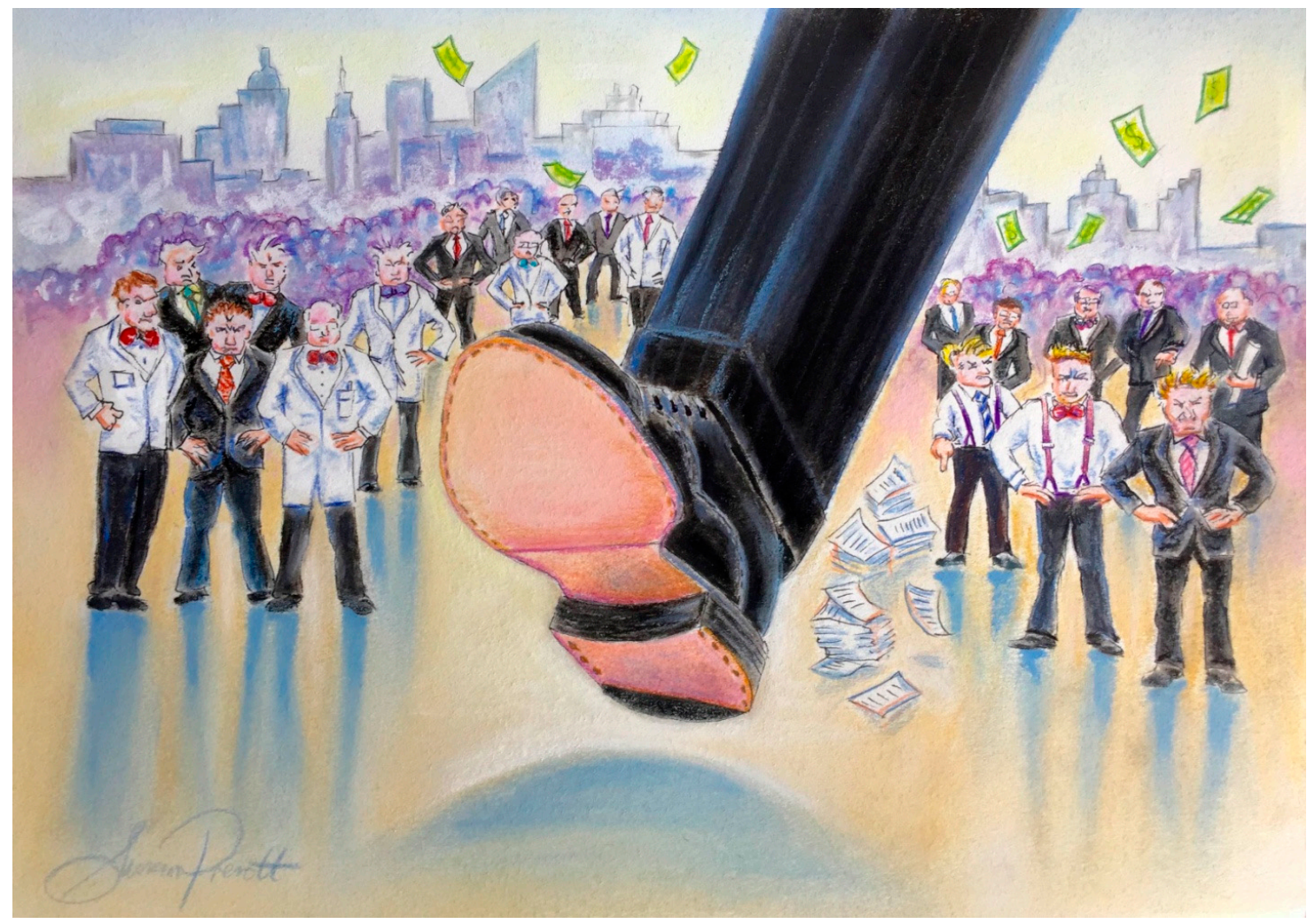

Figure 1. The total lived experience. To what extent does authoritarianism erode trust and compromise shared decision making, cultural competency, understanding values and patient-centered care in the age of non-communicable diseases?

Henry K. Beecher, the Harvard physician best known for advancing knowledge of the placebo was a sharp critic of Flexner. In one of his last writings, Beecher said the following: "Today's medicine, which many find irrelevant to the patients' needs, is the fruit of Flexner's report. This was not the first time, nor 
will it be the last, that medical education policy has come under the influence of a well-informed but short-sighted reformer" [138]. In medical education, Beecher favored the psychosocial aspects that provide essential context to laboratory breakthroughs. He sided with the noted Harvard medical scientist Lawrence J. Henderson, stating: "In a remarkable paper given in 1936 and received with almost total neglect, one of the greatest medical scientists this country or any other has ever produced, LJ Henderson, warned about regarding medicine as a branch or kind of science. He preferred to regard it as a branch of sociology" [138]. Henderson maintained that in the midst of medicine's advances within biological and mathematical sciences, the scientific and intellectual understanding of the patient-physician relationship was stuck in the days when, as he put it, Machiavelli was writing his famous works [139].

In order to illustrate the saliency of this topic-to fully appreciate how authoritarian barriers to the WHO goals in the Age of NCDs could manifest-consider the tragically high rates of suicide among veterans. Remarkably, there are twenty veteran suicides per day in the United States alone [140]. Although this may be due to many factors, not the least of which is inadequate access to primary forms of mental health care (e.g., pharmacotherapy, cognitive-behavioral interventions), the available treatments are undeniably inadequate. While skeptics scoff at traditional Eastern medicine, the practice of loving-kindness meditation may be helpful for veteran trauma and mind-body-spiritual growth [141,142].

The grieving families of deceased veterans are not likely to be concerned with righteous searches for absolutes in the scientific mechanisms of healing - mechanisms that may, or may not be, available two decades from now via lukewarm conclusions in a meta-analysis of loving kindness meditation. Nor are families likely to be interested in the authoritarian need to expunge the so-called placebo from all of medicine. In his famous 1934 address at Harvard University, Henderson made an important point concerning "truth" in the complexities of clinical practice: "there can be no sharp distinction between what is true and what is false... Far older than the precept, "the truth, the whole truth and nothing but the truth," is another that originates within our profession, that has always been the guide of the best physicians, and, if I may venture a prophecy, will always remain so: So far as possible, "do no harm." You can do harm by the process that is quaintly called telling the truth. You can do harm ... not only in treatment with drugs, or with the knife but also in treatment with words, with the expression of your sentiments and emotion" [139].

From our perspective, all groups who are vulnerable need protection from both poles-the charlatans offering cures at the one end and the other, the authoritarians who might suggest that culturally-appropriate traditional medicine and loving-kindness meditation offer no value. Patients with complex diseases and disorders, including unexplained symptoms which do not lend themselves to relatively simple solutions, are often labeled "difficult" [143]; these are the patients who are often "turfed" or "foisted," merry-go-round like, onto other physicians. In the final section below we will highlight Merrill's work which suggests that the same physician who is easily annoyed by patients-avoids complex cases and "turfs" patients on to other physicians - is likely to be the same authoritarian physician who would disparage loving-kindness meditation or any other traditional approaches to healing.

\section{Part IV}

\section{Tollo Causa: Research Questions and Future Directions}

For over half-a-century the professional discipline of medical sociology has studied medical students and their shifting values through different levels of training; the field has examined the student subcultures which develop in the face of intimidation and trial-by-ordeal during medical education [144] and has long-since concerned itself with issues such as the loss of idealism and benevolence and increases in cynicism during the progression of medical training [145]. Moreover, even as far back as the 1950s, medical sociologists have studied the perceptions of status and prestige granted (by students) to specialties such as surgery and reported that lower socioeconomic position among medical students influences expectations concerning specialty choices (more likely to expect to enter family practice) [146]. However, as acknowledged by leaders in the field, 'the sociology of medical 
education has remained marginal to the discipline as a whole, managing neither to influence medical education significantly, nor to keep up with theoretical developments in the broader field of sociology' [147].

Observers in the field of medical sociology have noted that the shuffling of medical curricula - which takes on the appearance of institutional reform-is without any substantive 'change' in the ways in which students prioritize technical 'competence' at the expense of patient 'care'; the pathway to meaningful change and the answers to some of the questions we pose below, necessitate a stronger presence of medical sociology and a comprehensive theory which accounts for the status quo [147]. In this section, we will present several lines of potential research and underscore that they should be placed into the greater context of the sociology of medical education and medical sociology in general. Concluding Part IV, we briefly provide the example of Pierre Bourdieu's concepts (applied to medical education) as a means to understand, through research, the otherwise fog-covered relationships between medical students, professors, teaching institutions, medicine as an institution-at-large and how these relationships are reinforced to maintain, rather than transform, a medical-social structure mismatched to the Age of NCDs [148,149].

First, given the research described above, it is clear that authoritarianism, social dominance orientation and Machiavellianism may be more prevalent in the candidates enrolled in western medical schools (than currently appreciated) and that medical training might further provoke the expression of these psychological liabilities. With so much at stake, it seems shocking, if not disheartening, that the work of Joseph H. Merrill and colleagues on authoritarianism [105], Machiavellianism [126] and intolerance for uncertainty [127] among medical students has largely gone unreferenced. Combined, these three separate studies have been cited only about 100 times on Google Scholar.

Since research also shows that these traits are not randomly distributed throughout medical specialties, it allows for the hypothesis that like-minded individuals find each other within certain groups. To underscore once again, these are, in general, objectionable traits, not only in medicine but through society. It is possible that some of the specific, individual-item components of the authoritarianism, social dominance orientation and/or Machiavellianism scales might be an asset when detachment is required (e.g., acute situations in an emergency room setting). This is worthy of scientific study. However, it would seem reasonable to query where these traits might concentrate and how they may potentially abuse the societal privilege of professional trust. For example, in matters of vaccine hesitancy and the encouragement of institutional trust in public health messages, research shows that authoritarian communication is not the solution [150,151].

Although these unhealthy attributes may only exist in a minority within western medicine, they are traits and expressed states that by their very nature can dominate the broad agenda. If the traits of authoritarianism, social dominance orientation and Machiavellianism do concentrate and coalesce, would they be identifiable as barriers to the WHO definition of health (fulfilment of potential) and the mandate of blended, culturally-sensitive global health? Researchers can match personality features and values with expressed positions on pathways to prevent and treat NCDs.

George Engel, the physician best known for popularizing the whole-person/whole-environment concept of biopsychosocial medicine put it this way: "Application of the biomedical model outside its limits is unscientific; advocacy of such application promotes dogma and is antiscientific" [152]. Thus, researchers might examine to what extent authoritarianism paradoxically promotes this anti-science in various channels at the expense of cultural competency and patient preferences. For example, researchers can employ content analysis to determine if authoritarianism and social dominance orientation presents itself on social media; researchers can look closely to determine if barriers to SDM and patient-centered care are found in attitudes and sentiments expressed outside treatment rooms-in the halls of social media. It is possible to examine not only offensive comments but also the motivations of social media users and link behavior to psychological needs as well as in-group vs. out-group dynamics [153]. Given the heavy social media use among some physicians—some sending dozens of tweets each day-it seems surprising that this area remains understudied. What we do know is that the professional implications of social media use are not top of mind among physicians $[154,155]$. 
While our focus here has been on SDO, authoritarianism and Machiavellianism, researchers are beginning to tease out some of the more desirable psychological assets among medical school candidates. For example, agreeableness is strongly and positively associated with empathic concern among medical students $[156,157]$. Higher agreeableness is linked to greater trust in others, altruism and humility; on the other hand, low agreeableness is associated with bullying, high skepticism, cynicism, egocentrism and social strategizing $[53,158,159]$. The personality differences of a large group of western medical students is exemplified by a study which examined those who were interested in taking elective courses in culturally-rooted traditional medicine during medical training vs. those who were not so inclined. The former had low interest in status (i.e., social reputation and income) as a driver in the decision to be a medical doctor and were more likely to be destined for family medicine. Among those who were not inclined, a sub-group of students (about 1/4 of 315 students) were identifiable by overt objections to traditional medicine perspectives; these latter students scored high on status motivations and low on agreeableness [160]. Agreeableness is negatively correlated with authoritarianism, SDO and Machiavellianism [161,162].

Agreeableness is also a key feature of cultural intelligence (CQ). Related to emotional intelligence, $\mathrm{CQ}$ is a validated measure of an individual's ability to work effectively with people from different cultural backgrounds [163]. Moving on from check-box measures of cultural competency, researchers are now exploring deeper channels to instill cultural consciousness and cultural humility which involves a greater depth of reflective awareness on the part of the student or practitioner. This requires the understanding of the physician's own personal assumptions, biases and values and then considering how these intersect with patients (their values, their total lived experience and beliefs in healing), all inside the context of grotesque social injustices and health disparities [26,28]. The idea of expressing cultural humility - which is an ongoing process, not a certificate program-may be difficult for those who crave social dominance and/or score high on authoritarianism.

Some research groups are already taking steps to evaluate the progress of medical students who have been specifically recruited in a way that emphasizes personality assets vs. purely science-based academic performance. For example, a multifaceted admissions procedure used by Goldman Medical School at Ben Gurion University incorporates computerized personality testing which has shifted the medical school enrollment toward higher levels of agreeableness, openness to experience and emotional stability. Over time this cohort may provide essential insight into the attributes which will produce compassionate physicians and social accountability in the Age of NCDs [164].

As mentioned earlier, the word 'values' is often included in statements concerning medical training and physician competency. Values serve as the guiding principles for the life of an individual. Thus, in a clinical setting, two sets of values intermingle-those belonging to the patient and those of the physician. Four of the 10 core personal values might be ripe for a standoff between physician and patient; that is, achievement, power and security vs. universalism, benevolence and tradition. The reader is referred to major reviews for further descriptions of these core values [20,165]. In short, power as a value is defined by prestige and social status, including authority and dominion over others. Security involves social order and achievement includes personal success and competence in the view of social standards. Benevolence involves the welfare of those in local circles (those with whom one makes frequent contact), while universalism is a value characterized by concern for both individuals and the natural environment-understanding, acceptance and tolerance for all, including those in the out-groups. Universalism also includes environmental and social justice. The value of tradition is related to respect, commitment and acceptance of the customs and ideas transmitted by traditional cultures. Thus, physicians are tasked with understanding these and other core values of patients. But such an effort will be less-than-optimal if physicians do not reflect upon their own values as they might interact with those of the patient.

The problem is that values are fairly rigid and make up a significant portion of social identity. If a student enters university oriented toward power, security and benevolence (vs. universalism) that's not likely to change much [20]. Indeed, medical students with lower baseline empathy may even 
magnify their biases as a result of required 'perspective taking' training [166]. Mindfulness training may have an important place in medical student wellbeing and empathy promotion [167] but when such courses become mandatory (vs. elective), the results are less impressive [168]. Thus, researchers should look more closely at responders vs. non-responders. Encouragingly, exposure to social sciences has been shown to reduce SDO, likely because it diminishes 'geneticism' or the biased view of genetic (rather than environmental) determinism [169]. Researchers might examine how personal values interact with SDO, Authoritarianism and Machiavellianism and how they relate, in turn, to patient outcomes and satisfaction. Moreover, researchers can also examine if there is clustering of certain personal values within medical specialties and institutions.

Merrill and colleagues examined some of the personality characteristics gathered on a graduating medial school class and compared them with responses to practice attitudes among these same physicians a decade later. Interestingly, those who had the highest scores on the 'science' component of the medical school entrance exam (Medical Colleges Admission Test or MCAT) had the highest needs for dominance and lowest needs for nurturance. Specific to patient care, they were also the most easily 'annoyed' and express antipathy to select patients in medical practice a decade later. Moreover, those who had the highest scores on the science portion of the MCAT were more likely to hold extreme ends of opinion on the Totalitarian-Authoritarian-Dogmatism questionnaire set up by the researchers [170]. Additional prospective research in large cohorts of medical students as they progress into careers would be essential to understanding how personality features, attitudes and values influence SDM and empathic care in the 21st century.

\section{Self-Inflicted Wounds}

"The assumption by physicians that they can put a price on the quality of life and advise on its achievement hardly seems justified in view of the fact that the rates of suicide, alcoholism, drug addiction and other social difficulties are higher among them than among comparable professional groups."

Rene J. Dubos, Pulitzer-Prize Winning Microbiologist [171].

We have outlined the patient and societal implications of ignoring something that appears broken. But the implications extend to physicians themselves, many of whom are caught up in unfriendly fire; they, too, are often victims of a broken system. Bullying, denigration, rudeness and micro-aggressions operate inside medicine, its hierarchies and among its more vocal social media operatives [172,173]. Indeed, evidence indicates that this physician-on-physician pecking (which has serious implications to physician health and performance [174]) is slanted from technical specialties toward general practitioners and other specialties where patient engagement is high [175-177]. As recently described by the president of the Canadian Federation of Medical Students concerning the trickle-down physician-on-physician bullying, "tolerating abuse is too often part of the 'hidden curriculum' of medical training" [178]. Indeed, workplace bullying increases Machiavellianism in its victims; this may be a 'survival' mechanism, modeling observed behavior, or both [179].

When researchers uncover bullying and teaching by humiliation in medical school, the professional response is one of "surprise"; but intimidation and humiliation remain widespread [180,181]. It is noteworthy that such rates of humiliation during medical training (that is, experiencing and/or witnessing humiliation) are lower during pediatric training [182], as this might link to (the aforementioned) separate research demonstrating lower rates of SDO, authoritarianism and Machiavellianism among pediatricians or medical students destined for the specialty. This is not celebratory research for pediatricians or an inference that pediatricians are more virtuous; rather it is a call to determine if there are linear connections between pre-medical school attitudes, medical training, medical specialty choice, post-graduate attitudes in practice, cyberbullying of out-groups, as well as the institutional 'personality' of medicine at-large. 
While academics have outlined dozens of compelling attributes that might make for the best doctors in candidacy/recruitment, there should be fundamental agreement about what characteristics might be poisonous to the cultural competency of medicine in the 21st century. Albanese and colleagues point out, "the cunning ability of applicants and preparation services" to contaminate the system of medical candidate assessment (of personal qualities) is a formidable challenge [183]. Medical candidates will undoubtedly attempt to work around scales of SDO, authoritarianism, Machiavellianism, etc.; thus, gatekeepers should be two steps ahead with embedding special indicators of social desirability and over-claiming within assessments [184]. Follow-up and wide replication of Merrill's work will require assessments of social desirability biases, including impression management (presenting oneself in a manner tailored to the audience) and positive self-deception (ignore less desirable aspects of oneself and behavior) [185].

In its desire to be universally perceived as expert in all things related to health (as opposed to only disease), medicine as an institution may be undermining societal trust. Restoration of trust in medicine as an institution may be found in its admission that other professions may actually be 'uniquely suited' (as it is oft-phrased) to provide leadership, far more than physicians, in the Age of NCDs. To maintain the status quo, especially when the system of western biomedicine medicine affords patients only a few minutes per visit [186] to express their symptoms, not to mention their values, seems untenable. Unless the medical system is transformed toward longer interactions with patients, the most effective skill of the physician as it pertains to lifestyle health might be referral to others [187]. Researchers might ask to what extent public trust would increase if medicine as an institution took more potent steps to self-reflect and evaluate some of its authoritarian optics.

Community engaged medical education-active involvement by the community (including the local health care system normally considered "external" to academic institutions) in medical education may help to flatten hierarchies and institutional power dynamics; when the community is actively involved in the medical school's activities-its mission statements, priorities and outcome measurements-medical school and student accountability may be found in ways not captured by multiple choice board exams [188]. As researchers evaluate the potential of community engaged medical education in achieving health equity, they may also evaluate the attributes of the students best suited to engage in the inter-disciplinary care which makes up the 'community' of providers (some of whom may use loving-kindness meditation or other such non-traditional, culturally-rooted approaches) who work toward promoting the WHO definition of health and wellness.

Finally, in the midst of opening up a dialogue on the authoritarianism, social dominance orientation and Machiavellianism (and the absence of inter-professional and 'lifestyle' approaches to patient care) we underscore that a more detailed understanding of the barriers to change ultimately requires a comprehensive, testable, theory which can help explain the maintenance of the status-driven status quo. Medical sociologist Caragh Brosnan has proposed the use of Pierre Bourdieu's concepts of habitus, field and capital to activate a more reasoned understanding of medical education and its ultimate 'product' [148]. Specifically, how can Bourdieu's theoretical framework help scientists and educators work toward new ways of thinking such that freshly-graduated students and the medical profession-at-large is ready to 'care' for patients and promote the aims of the WHO definition of health at local and global levels.

Briefly, Bourdieu's habitus refers to the total lived experience over time, experiences (especially early in life) which shape our habits, skills and dispositions. Capital refers to accumulated resources; not simply economic in nature, Bourdieu considered cultural capital to be an important part of personal resources. For example, university degrees and titles (such as "doctor") would be considered institutionalized cultural capital. At the group level this provides collective identity and can be seen in statements such as "we, in science and medicine." Cultural capital includes "tastes," posturing, clothing (from our perspective this includes white coats, bowties), material goods and mannerisms which can facilitate access to 'higher' social capital. Habitus and capital operate, or are 'played,' within distinct (capable of overlapping) ecological theatres known as the 'field.' The field maintains unique 
sets of rules, bodies of knowledge and social capital. Inside this theatre various actors use capital to struggle for legitimacy and position. The 'game' or 'play' within the theatre does not operate on a level playing field. Certain individuals enter the field with habitus and capital which dominates; habitus reproduces the field and the field continually seeds habitus [189].

According to Brosnan and others, Bourdieusian analysis will allow researchers to move beyond the student-centered focus (that is, looking only at medical enculturation through student experiences) and consider the concomitant influence of organizational structures inside and outside the walls of medical schools. Technical competence is currently a far more valuable form of social capital in the field of medicine (both within the medical school and medicine as a larger institution) than is the knowledge and competence associated with 'caring' or attending to lifestyle. Applying Bourdieu's concepts can provide research-based tools to understand why that reality remains stuck in place [148]. As stated by experts Andrea Patricia Gomes and Sergio Rego:

"Changing medical training means building a different field with different social agents, it means forming new ways of thinking, new ways of operating, it means changing considering the social structure that perpetuates itself in the action of and readjustment of the individuals themselves, who act according to the incorporated models and arrangements" [149].

\section{Conclusions}

We are hopeful that our discussion of authoritarianism in medicine will represent a jumping off point for research into an understudied area with enormous implications to society. The research is far from robust in this realm and there are far more questions than answers. However, there is more than enough existing research - much of which is ignored and unreferenced by medicine-at-large-from which to query the extent to which the Flexnarian status quo acts as a barrier to WHO goals. The ecological and psychosocial road less traveled after Flexner's report is still unpaved compared to the biomedicine superhighway. Discussions of personalities and priorities may be important with regard to the stalled construction of a unifying road to health, one in which words like values actually have meaning.

Much has been written concerning the personalities, psyche and so-called magical thinking of individuals and groups who adhere to conspiracy theories and engage in fringe alternative practices while rejecting orthodox medicine [190]. But what do we know about the opposite pole, the fringes at the extremes of scientism and authoritarianism in medicine? How would that knowledge aid in addressing the barriers to human health? The evidence explored here suggests we do not know nearly enough. We can only conclude that it might be helpful to know more about the psyche of those who rigidly cling to the idea that the same applied science that develops rockets and particle accelerators can also be forced to fit-Rosetta Stone-like-into the ecological complexities of human health and healing.

As stated at the outset, our commentary is provided with the understanding that western biomedicine provides invaluable benefits to society; the 20th century was one of phenomenal advances in scientific medicine; successes with antibiotics, effective vaccines, surgical techniques and diagnostics transformed human health and wellbeing, particularly with the abatement of single-agent infectious diseases. However, there is abundant evidence from the annals of public health research that institutions with vested interests (e.g., tobacco, ultra-processed foods) can use science in sectarian ways, helping to shape public opinion along the way [191-193]. These references and others demonstrate that collective aspects of power-based dynamics can act as a barrier to health promotion; but only properly conducted research can determine the extent to which westernized, biomedicine-dominated medicine maintains the fallacious notion of lifestyle expertise vis-à-vis societal trust—simply because to admit otherwise is a threat to status.

In the meantime, individuals, websites and organizations proclaiming to be acting in the interest of science and evidence-based medicine would probably agree that SDO, authoritarianism, elitism, racial biases and Machiavellianism should be investigated and limited upstream of medical training 
and practice. If for no other reason, it should be obvious that 'Best Practices' will never be best when they are delivered by culturally-insensitive individuals/organizations rigidly attached to prestige, money, domination and the belief that certain people/groups should be allocated less positive social value. An individual can have magnificent scores in undergraduate organic chemistry and the Medical Colleges Admission Test but that does not mean they are society's best candidate for medicine in the Age of NCDs.

Flexner referred to alternative forms of healing as sects; he certainly had plenty of justifiable reasons to make such a claim. Collectively, however, the attributes of authoritarianism, social dominance orientation and Machiavellianism could also be the hallmarks of those who might cling to a different sort of rigid sect. At the group level, the combination of maintaining the fallacy of physician as lifestyle health expert and rigid opposition to expansion of practice by allied health professionals, takes on sect-like characteristics. These are serious questions for societies in which personal, public health and planetary health are deeply intertwined and in which the non-communicable, lifestyle variants of diseases are a global threat. Concerned about some of the deficits in Flexner's report-its elitism, curt dismissal of an ignorant public, concentration of wealth and power into select institutions-and the ways in which this collective might influence the future of medicine, the Editorial Board of the Medical Standard (1910) responded in a manner that is no less relevant today:

"The public has standards of its own ... which, however the academicians may scoff at it, has always been, is now and will continue to be, as long as medical science shall last, the final and indeed the only valid test of professional efficiency; a standard by which the whole function of medicine, in all of its aspects, must justify itself to civilization, or, failing, is estopped from pleading any other laudable attainment. That standard is the standard of results. In the public estimation-and we have ultimately no other bar at which to answer - the old criterion still remains in effect, cito, tuto, et jueunde curare (rapid, safe and gentle restoration of health). By this touchstone shall all medical agencies be tried" [194].

Fast-forward a century and now Yelp on-line physician reviews can allow the public to weigh in on what the Medical Standard editors called 'professional efficiency' [195]. Today, the public can 'speak up' when they see elitism, social dominance and the hallmarks of authoritarianism. Of course, the internet is overflowing with misinformation, bogus remedies and long-debunked conspiracy theories-but they sit side-by-side with the mythical ideas propagated by medical authoritarianism, including the notion that allowing nurse practitioners and pharmacists to prescribe medications and administer vaccines is a threat to public health! Yet, there is valuable public health information there, too. This includes the WebPages of patient support groups where they get to tell their stories. These are the stories that are otherwise called 'values' and 'preferences' but are often reduced to a check-off box in training. Ultimately, just as surely as physicians inform the public, the internet has allowed the public to inform the minority of 'difficult' physicians.

Acknowledgments: No funding was used for this manuscript.

Author Contributions: Both authors contributed equally to the intellectual input, research and manuscript development.

Conflicts of Interest: S.L.P. reports the following: Scientific Advisory Board and speakers fees from Danone Nutricia, Schiphol, Netherlands and Nestlé Nutrition Institute, Lausanne, Switzerland; consultancy fees from Bayer Dietary Supplements Division, Whippany, NJ, USA; speakers fees from Health World Inc., Queensland, Australia. A.C.L. has received consultancy fees from Genuine Health, Toronto, Canada and speakers fees from Health World Inc., Queensland, Australia.

\section{References}

1. Allen, L. Are we facing a noncommunicable disease pandemic? J. Epidemiol. Glob. Health 2017, 7, 5-9. [CrossRef] [PubMed]

2. Smith, K. Trillion-dollar brain drain. Nature 2011, 478, 15. [CrossRef] [PubMed] 
3. Bouchery, E.E.; Harwood, H.J.; Sacks, J.J.; Simon, C.J.; Brewer, R.D. Economic costs of excessive alcohol consumption in the U.S., 2006. Am. J. Prev. Med. 2011, 41, 516-524. [CrossRef] [PubMed]

4. Hansen, R.N.; Oster, G.; Edelsberg, J.; Woody, G.E.; Sullivan, S.D. Economic costs of nonmedical use of prescription opioids. Clin. J. Pain 2011, 27, 194-202. [CrossRef] [PubMed]

5. Al-Rousan, T.; Rubenstein, L.; Sieleni, B.; Deol, H.; Wallace, R.B. Inside the nation's largest mental health institution: A prevalence study in a state prison system. BMC Public Health 2017, 17, 342. [CrossRef] [PubMed]

6. World Health Organization. Constitution of WHO: Principles. Available online: http://www.who.int/ about/mission/en/ (accessed on 22 February 2018).

7. Moisiadis, V.G.; Constantinof, A.; Kostaki, A.; Szyf, M.; Matthews, S.G. Prenatal Glucocorticoid Exposure Modifies Endocrine Function and Behaviour for 3 Generations Following Maternal and Paternal Transmission. Sci Rep. 2017, 7, 11814. [CrossRef] [PubMed]

8. Hao, C.; Gely-Pernot, A.; Kervarrec, C.; Boudjema, M.; Becker, E.; Khil, P.; Tevosian, S.; Jégou, B.; Smagulova, F. Exposure to the widely used herbicide atrazine results in deregulation of global tissue-specific RNA transcription in the third generation and is associated with a global decrease of histone trimethylation in mice. Nucleic Acids Res. 2016, 44, 9784-9802. [CrossRef] [PubMed]

9. Huypens, P.; Sass, S.; Wu, M.; Dyckhoff, D.; Tschop, M.; Theis, F.; Marschall, S.; Hrabě de Angelis, M.; Beckers, J. Epigenetic germline inheritance of diet-induced obesity and insulin resistance. Nat. Genet. 2016, 48, 497-499. [CrossRef] [PubMed]

10. Ambeskovic, M.; Roseboom, T.J.; Metz, G.A.S. Transgenerational effects of early environmental insults on aging and disease incidence. Neurosci. Biobehav. Rev. 2017. [CrossRef] [PubMed]

11. Poutahidis, T.; Varian, B.J.; Levkovich, T.; Lakritz, J.R.; Mirabal, S.; Kwok, C.; Ibrahim, Y.M.; Kearney, S.M.; Chatzigiagkos, A.; Alm, E.J.; et al. Dietary microbes modulate transgenerational cancer risk. Cancer Res. 2015, 75, 1197-1204. [CrossRef] [PubMed]

12. Logan, A.C.; Prescott, S.L. Astrofood, priorities and pandemics: Reflections of an ultra-processed breakfast program and contemporary dysbiotic drift. Challenges 2017, 8, 24. [CrossRef]

13. Allen, L.N.; Feigl, A.B. What's in a name? A call to reframe non-communicable diseases. Lancet Glob. Health 2017, 5, e129-e130. [CrossRef]

14. WHO Traditional Medicine Strategy: 2014-2023. Available online: http://apps.who.int/iris/bitstream/ 10665/92455/1/9789241506090_eng.pdf (accessed on 22 June 2017).

15. World Health Organization. Montevideo Roadmap 2018-2030 on NCDs as a Sustainable Development Priority. In Proceedings of the WHO Global Conference on Noncommunicable Diseases, Montevideo, Uruguay, 18-20 October 2017.

16. Chopra, M.; Galbraith, S.; Darnton-Hill, I. A global response to a global problem: The epidemic of overnutrition. Bull. World Health Organ. 2002, 80, 952-958. [PubMed]

17. Prescott, S.L.; Logan, A.C.; Millstein, R.A.; Katszman, M.A. Biodiversity, the Human Microbiome and Mental Health: Moving Toward a New Clinical Ecology for the 21st Century? Int. J. Biodivers. 2016, 2016, 2718275. [CrossRef]

18. Prescott, S.L.; Logan, A.C. Transforming Life: A Broad View of the Developmental Origins of Health and Disease Concept from an Ecological Justice Perspective. Int. J. Environ. Res. Public Health 2016, 13, 1075. [CrossRef] [PubMed]

19. Committee on Quality of Health Care in America and Institute of Medicine: Crossing the Quality Chasm: A New Health System for the 21st Century; National Academies Press: Washington, DC, USA, 2001.

20. Sagiv, L.; Roccas, S.; Cieciuch, J.; Schwartz, S.H. Personal values in human life. Nat. Hum. Behav. 2017, 1, 630-639. [CrossRef]

21. Taylor, Y.J.; Tapp, H.; Shade, L.E.; Liu, T.L.; Mowrer, J.L.; Dulin, M.F. Impact of shared decision making on asthma quality of life and asthma control among children. J. Asthma 2017, 1-9. [CrossRef] [PubMed]

22. Liu, T.L.; Taylor, Y.J.; Mahabaleshwarkar, R.; Blanchette, C.M.; Tapp, H.; Dulin, M.F. Shared decision making and time to exacerbation in children with asthma. J. Asthma 2017, 1-7. [CrossRef] [PubMed]

23. Braddock, C.H., 3rd; Fihn, S.D.; Levinson, W.; Jonsen, A.R.; Pearlman, R.A. How doctors and patients discuss routine clinical decisions. Informed decision making in the outpatient setting. J. Gen. Intern. Med. 1997, 12, 339-345. [PubMed] 
24. Kumas-Tan, Z.; Beagan, B.; Loppie, C.; MacLeod, A.; Frank, B. Measures of cultural competence: Examining hidden assumptions. Acad. Med. 2007, 82, 548-557. [CrossRef] [PubMed]

25. Jernigan, V.B.; Hearod, J.B.; Tran, K.; Norris, K.C.; Buchwald, D. An Examination of Cultural Competence Training in US Medical Education Guided by the Tool for Assessing Cultural Competence Training. J. Health Disparities Res. Pract. 2016, 9, 150-167.

26. Kumagai, A.K.; Lypson, M.L. Beyond cultural competence: Critical consciousness, social justice and multicultural education. Acad. Med. 2009, 84, 782-787. [CrossRef] [PubMed]

27. Amutairi, A.F.; Dahinten, V.S. Factor structure of Almutairi's Critical Cultural Competence Scale. Admin. Sci. 2017, 7, 13. [CrossRef]

28. Yeager, K.A.; Bauer-Wu, S. Cultural humility: Essential foundation for clinical researchers. Appl. Nurs. Res. 2013, 26, 251-256. [CrossRef] [PubMed]

29. Rajaram, S.S.; Bockrath, S. Cultural competence: New conceptual insights into its limits and potential for addressing health disparities. J. Health Disparities Res. Pract. 2014, 7, 82-89.

30. Couet, N.; Desroches, S.; Robitaille, H.; Vaillancourt, H.; Leblanc, A.; Turcotte, S.; Elwyn, G.; Légaré, F. Assessments of the extent to which health-care providers involve patients in decision making: A systematic review of studies using the OPTION instrument. Health Expect 2015, 18, 542-561. [CrossRef] [PubMed]

31. Hamann, J.; Mendel, R.; Buhner, M.; Kissling, W.; Cohen, R.; Knipfer, E.; Eckstein, H.H. How should patients behave to facilitate shared decision making-The doctors' view. Health Expect 2012, 15, 360-366. [CrossRef] [PubMed]

32. Leeder, S.; Corbett, S.; Usherwood, T. General practice registrar education beyond the practice: The public health role of general practitioners. Aust. Fam. Physician 2016, 45, 266-269. [PubMed]

33. Hubinette, M.M.; Ajjawi, R.; Dharamsi, S. Family physician preceptors' conceptualizations of health advocacy: Implications for medical education. Acad. Med. 2014, 89, 1502-1509. [CrossRef] [PubMed]

34. Frank, J.R.; Snell, L.; Sherbino, J. (Eds.) CanMEDS 2015 Physician Competency Framework. Ottawa: Royal College of Physicians and Surgeons of Canada; The Royal College of Physicians and Surgeons of Canada: Ottawa, ON, Canada, 2015; Available online: http:/ / canmeds.royalcollege.ca/en/framework (accessed on 22 February 2018).

35. Hubinette, M.; Dobson, S.; Scott, I.; Sherbino, J. Health advocacy. Med. Teach. 2017, 39, 128-135. [CrossRef] [PubMed]

36. Peachman, R.R. What You Do not Know About Your Doctor Could Hurt You. Consum. Rep. 2016, 81, $30-43$. [PubMed]

37. Marmot, M. Post-truth and science. Lancet 2017, 389, 497-498. [CrossRef]

38. Hines, H.G.; Avila, C.J.; Rudakevych, T.M.; Curlin, F.A.; Yoon, J.D. Physician Perspectives on Long-Term Relationships and Friendships with Patients: A National Assessment. South Med. J. 2017, 110, 679-684. [CrossRef] [PubMed]

39. Blendon, R.J.; Benson, J.M.; Hero, J.O. Public trust in physicians-U.S. medicine in international perspective. N. Engl. J. Med. 2014, 371, 1570-1572. [CrossRef] [PubMed]

40. Schmit, C.D.; Penn, M.S. Expanding state laws and a growing role for pharmacists in vaccination services. J. Am. Pharm. Assoc. (2003) 2017, 57, 661-669. [CrossRef] [PubMed]

41. Timmons, E.J. The effects of expanded nurse practitioner and physician assistant scope of practice on the cost of Medicaid patient care. Health Policy 2017, 121, 189-196. [CrossRef] [PubMed]

42. DePillis, L. In a fight between nurses and doctors, the nurses are slowly winning. The Washington Post, 18 March 2016.

43. Tsuyuki, R.T.; Rosenthal, M.; Pearson, G.J. A randomized trial of a community-based approach to dyslipidemia management: Pharmacist prescribing to achieve cholesterol targets (RxACT Study). Can. Pharm. J. 2016, 149, 283-292. [CrossRef] [PubMed]

44. Wilkes, M.; Kennedy, R. Interprofessional Health Sciences Education: It's Time to Overcome Barriers and Excuses. J. Gen. Intern. Med. 2017, 32, 858-859. [CrossRef] [PubMed]

45. World Health Organisation. Framework for Action on Interprofessional Education and Collaborative Practice; World Health Organisation: Geneva, Switzerland, 2010; Available online: http://apps.who.int/iris/bitstream/ 10665/70185/1/WHO_HRH_HPN_10.3_eng.pdf?ua=1 (accessed on 22 February 2018). 
46. Darlow, B.; Coleman, K.; McKinlay, E.; Donovan, S.; Beckingsale, L.; Gray, B.; Neser, H.; Perry, M.; Stanley, J.; Pullon, $\mathrm{S}$. The positive impact of interprofessional education: A controlled trial to evaluate a programme for health professional students. BMC Med. Educ. 2015, 15, 98. [CrossRef] [PubMed]

47. Tannenbaum, D.; Kerr, J.; Konkin, J.; Organek, A.; Parsons, E.; Saucier, D.; Shaw, L.; Walsh, A. Length of Training in the Core Family Medicine Residency: Report of the Working Group on Postgraduate Curriculum Review; College of Family Physicians of Canada: Mississauga, ON, Canada, 2012.

48. Peterson, O.L.; Andrews, L.P.; Spain, R.S.; Greenberg, B.G. An Analytical study of North Carolina general practice 1953-1954. J. Med. Educ. 1956, 31, 1-165.

49. Greene, J.A.; Jones, D.S. The Shared Goals and Distinct Strengths of the Medical Humanities: Can the Sum of the Parts Be Greater Than the Whole? Acad. Med. 2017, 92, 1661-1664. [CrossRef] [PubMed]

50. Freeman, J.V.; Collier, S.; Staniforth, D.; Smith, K.J. Innovations in curriculum design: A multi-disciplinary approach to teaching statistics to undergraduate medical students. BMC Med. Educ. 2008, 8, 28. [CrossRef] [PubMed]

51. Blanco, M.A.; Capello, C.F.; Dorsch, J.L.; Perry, G.; Zanetti, M.L. A survey study of evidence-based medicine training in US and Canadian medical schools. J. Med. Libr. Assoc. 2014, 102, 160-168. [CrossRef] [PubMed]

52. Wilkes, M. Hidden Agendas Teaching and Learning in Medicine. In Professional Responsibility. Advances in Medical Education; Mitchell, D., Ream, R., Eds.; Springer International: Cham, Switzerland, 2017; Volume 4, pp. 141-154.

53. Chibnall, J.T.; Blaskiewicz, R.J.; Detrick, P. Are medical students agreeable? An exploration of personality in relation to clinical skills training. Med. Teach. 2009, 31, e311-e315. [CrossRef] [PubMed]

54. Association of American Medical Colleges. Recommendations for Clinical Skills Curricula for Undergraduate Medical Education. Task Force on the Clinical Skills Education of Medical Students; Association of American Medical Colleges: Washington, DC, USA, 2005; Available online: https://www.aamc.org/initiatives/ clinicalskills / (accessed on 22 February 2018).

55. Holtz, K.A.; Kokotilo, K.J.; Fitzgerald, B.E.; Frank, E. Exercise behaviour and attitudes among fourth-year medical students at the University of British Columbia. Can. Fam. Physician 2013, 59, e26-e32. [PubMed]

56. Dunlop, M.; Murray, A.D. Major limitations in knowledge of physical activity guidelines among UK medical students revealed: Implications for the undergraduate medical curriculum. Br. J. Sports Med. 2013, 47, 718-720. [CrossRef] [PubMed]

57. Cardinal, B.J.; Park, E.A.; Kim, M.; Cardinal, M.K. If Exercise is Medicine, Where is Exercise in Medicine? Review of U.S. Medical Education Curricula for Physical Activity-Related Content. J. Phys. Activ. Health 2015, 12, 1336-1343. [CrossRef] [PubMed]

58. Strong, A.; Stoutenberg, M.; Hobson-Powell, A.; Hargreaves, M.; Beeler, H.; Stamatakis, E. An evaluation of physical activity training in Australian medical school curricula. J. Sci. Med. Sport 2017, 20, 534-538. [CrossRef] [PubMed]

59. Adams, K.M.; Kohlmeier, M.; Zeisel, S.H. Nutrition education in U.S. medical schools: Latest update of a national survey. Acad. Med. 2010, 85, 1537-1542. [CrossRef] [PubMed]

60. Cuerda, C.; Schneider, S.M.; Van Gossum, A. Clinical nutrition education in medical schools: Results of an ESPEN survey. Clin. Nutr. 2017, 36, 915-916. [CrossRef] [PubMed]

61. Kahan, S.; Kushner, R.F. Nutrition in Clinical Medicine: A Core Competency for Healthcare Providers. Med. Clin. N. Am. 2016, 100, xvii-xx. [CrossRef] [PubMed]

62. Devries, S.; Agatston, A.; Aggarwal, M.; Aspry, K.E.; Esselstyn, C.B.; Kris-Etherton, P.; Miller, M.; O'Keefe, J.H.; Ros, E.; Rzeszut, A.; et al. A Deficiency of Nutrition Education and Practice in Cardiology. Am. J. Med. 2017, 130, 1298-1305. [CrossRef] [PubMed]

63. Castillo, M.; Feinstein, R.; Tsang, J.; Fisher, M. Basic nutrition knowledge of recent medical graduates entering a pediatric residency program. Int. J. Adolesc. Med. Health 2016, 28, 357-361. [CrossRef] [PubMed]

64. Castillo, M.; Feinstein, R.; Tsang, J.; Fisher, M. An assessment of basic nutrition knowledge of adolescents with eating disorders and their parents. Int. J. Adolesc. Med. Health 2015, 27, 11-17. [CrossRef] [PubMed]

65. Castillo, M.; Feinstein, R.; Fischer, M. Nutrition knowledge of medical graduates. J. Adv. Nutr. Hum. Metab. 2016, 2, e1188.

66. Temple, N.J. Survey of nutrition knowledge of Canadian physicians. J. Am. Coll. Nutr. 1999, 18, $26-29$. [CrossRef] [PubMed] 
67. Raman, M.; Violato, C.; Coderre, S. How much do gastroenterology fellows know about nutrition? J. Clin. Gastroenterol. 2009, 43, 559-564. [CrossRef] [PubMed]

68. Vetter, M.L.; Herring, S.J.; Sood, M.; Shah, N.R.; Kalet, A.L. What do resident physicians know about nutrition? An evaluation of attitudes, self-perceived proficiency and knowledge. J. Am. Coll. Nutr. 2008, 27, 287-298. [CrossRef] [PubMed]

69. Flynn, M.; Sciamanna, C.; Vigilante, K. Inadequate physician knowledge of the effects of diet on blood lipids and lipoproteins. Nutr. J. 2003, 2, 19. [CrossRef] [PubMed]

70. Hargrove, E.J.; Berryman, D.E.; Yoder, J.M.; Beverly, E.A. Assessment of nutrition knowledge and attitudes in preclinical osteopathic medical students. J. Am. Osteopath. Assoc. 2017, 117, 622-633. [CrossRef] [PubMed]

71. Patel, S.; Taylor, K.H.; Berlin, K.L.; Geib, R.W.; Robin Danek, R.; Waite, G.N. Nutrition Education in U.S. Medical Schools: An Assessment of Nutrition Content in USMLE STEP Preparation Materials. J. Curric. Teach. 2015, 4, 108-113. [CrossRef]

72. Whitaker, K.M.; Wilcox, S.; Liu, J.; Blair, S.N.; Pate, R.R. Provider Advice and Women's Intentions to Meet Weight Gain, Physical Activity and Nutrition Guidelines During Pregnancy. Matern. Child Health J. 2016, 20, 2309-2317. [CrossRef] [PubMed]

73. Lee, A.; Belski, R.; Radcliffe, J.; Newton, M. What do Pregnant Women Know About the Healthy Eating Guidelines for Pregnancy? A Web-Based Questionnaire. Matern. Child Health J. 2016, 20, 2179-2188. [CrossRef] [PubMed]

74. Zeev, Y.B.; Bonevski, B.; Twyman, L.; Watt, K.; Atkins, L.; Palazzi, K.; Oldmeadow, C.; Gould, G.S. Opportunities Missed: A Cross-Sectional Survey of the Provision of Smoking Cessation Care to Pregnant Women by Australian General Practitioners and Obstetricians. Nicotine Tobacco Res. 2017, 19, 636-641. [CrossRef] [PubMed]

75. Chatterjee, R.; Chapman, T.; Brannan, M.G.; Varney, J. GPs' knowledge, use and confidence in national physical activity and health guidelines and tools: A questionnaire-based survey of general practice in England. Br. J. Gen. Pract. 2017, 67, e668-e675. [CrossRef] [PubMed]

76. Talwalkar, A.; McCarty, F. Characteristics of Physician Office Visits for Obesity by Adults Aged 20 and Over: United States, 2012. NCHS Data Brief 2016, 237, 1-8.

77. Williams, K.; Beeken, R.J.; Fisher, A.; Wardle, J. Health professionals' provision of lifestyle advice in the oncology context in the United Kingdom. Eur. J. Cancer Care 2015, 24, 522-530. [CrossRef] [PubMed]

78. Bott, D.; Huntjens, B.; Binns, A. Nutritional and smoking advice recalled by patients attending a UK age-related macular degeneration clinic. J. Public Health 2017, 1-9. [CrossRef] [PubMed]

79. Huber, M.; Knutti, R. Anthropogenic and natural warming inferred from changes in Earth's energy balance. Nat. Geosci. 2012, 5, 31-36. [CrossRef]

80. Lancet, O. Climate change and non-communicable diseases. Lancet Oncol. 2016, 17, 1.

81. Sarfaty, M.; Bloodhart, B.; Ewart, G.; Thurston, G.D.; Balmes, J.R.; Guidotti, T.L.; Maibach, E.W. American Thoracic Society member survey on climate change and health. Ann. Am. Thorac. Soc. 2015, 12, 274-278. [CrossRef] [PubMed]

82. Sarfaty, M.; Kreslake, J.M.; Bloodhart, B.; Price, K.; Montoro, M.; Casale, T.B.; Folstein, S.; Maibach, E. George Mason University Centre for Climate Change Communication: Views of Allergy Specialists on Health Effects of Climate Change 2015. Available online: https: / / www.aaaai.org/Aaaai/media/MediaLibrary/ PDFDocuments/Libraries/Climate-Change-Survey.pdf (accessed on 22 February 2018).

83. Sarfaty, M.; Kreslake, J.M.; Casale, T.B.; Maibach, E.W. Views of AAAAI members on climate change and health. J. Allergy Clin. Immunol. Pract. 2016, 4, 333-335. [CrossRef] [PubMed]

84. Washburn, A.N.; Skitka, L.J. Science denial across the political divide: Liberals and conservatives are similarly motivated to deny attitude-inconsistent science. Soc. Psychol. Personal. Sci. 2017, in press. [CrossRef]

85. Faunce, T.A.; Gatenby, P. Flexner's ethical oversight reprised? Contemporary medical education and the health impacts of corporate globalisation. Med. Educ. 2005, 39, 1066-1074. [CrossRef] [PubMed]

86. Flexner, A. Medical Education in the United States and Canada: A Report to the Carnegie Foundation for the Advancement of Teaching; The Carnegie Foundation for the Advancement of Teaching: New York, NY, USA, 1910.

87. Engel, G.L. Biomedicine's failure to achieve Flexnerian standards of education. J. Med. Educ. 1978, 53, 387-392. [PubMed] 
88. Tauber, A.I. The two faces of medical education: Flexner and Osler revisited. J. R. Soc. Med. 1992, 85, 598-602. [PubMed]

89. Hart, J.T. A new kind of doctor. J. R. Soc. Med. 1981, 74, 871-883. [CrossRef] [PubMed]

90. Woollard, R.; Buchman, S.; Meili, R.; Strasser, R.; Alexander, I.; Goel, R. Social accountability at the meso level: Into the community. Can. Fam. Physician 2016, 62, 538-540. [PubMed]

91. Adorno, T.W.; Frenkel-Brunswik, E.; Levinson, D.J.; Sanford, R.N. The Authoritarian Personality; Harper: New York, NY, USA, 1950.

92. Stenner, K. The Authoritarian Dynamic; Cambridge University Press: Cambridge, UK, 2005.

93. Martinez-Zambrano, F.; Garcia-Morales, E.; Garcia-Franco, M.; Miguel, J.; Villellas, R.; Pascual, G.; Arenas, O.; Ochoa, S. Intervention for reducing stigma: Assessing the influence of gender and knowledge. World J. Psychiatry 2013, 3, 18-24. [CrossRef] [PubMed]

94. Hammond, M.D.; Cimpian, A. Investigating the cognitive structure of stereotypes: Generic beliefs about groups predict social judgments better than statistical beliefs. J. Exp. Psychol. Gen. 2017, 146, 607-614. [CrossRef] [PubMed]

95. Asbrock, F.; Kauff, M. Authoritarian Disbeliefs in Diversity. J. Soc. Psychol. 2015, 155, 553-558. [CrossRef] [PubMed]

96. McKee, M. Health professionals must uphold truth and human rights. Eur. J. Public Health 2017, $27,6-7$. [CrossRef] [PubMed]

97. Greer, S.L. Medicine, public health and the populist radical right. J. R. Soc. Med. 2017, 110, 305-308. [CrossRef] [PubMed]

98. Cockerham, W.C. The New Blackwell Companion to Medical Sociology; John Wiley and Sons: West Sussex, UK, 2010.

99. Scrambler, G. Medical Sociology: Major Themes in Health and Social Welfare; Routledge: London, UK, 2005.

100. Scrambler, G. Habermas, Critical Theory and Health; Routledge: London, UK, 2001.

101. Zakaria, F.; Zainal, H. Traditional Malay medicine in Singapore. Indones. Malay World 2017, 131, $127-144$. [CrossRef]

102. Adams, J.; Hollenberg, D.; Lui, C.W.; Broom, A. Contextualizing integration: A critical social science approach to integrative health care. J. Manipulative Physiol. Ther. 2009, 32, 792-798. [CrossRef] [PubMed]

103. Duckitt, J. Authoritarian Personality. In International Encyclopedia of the Social E Behavioral Sciences, 2nd ed.; Wright, J.D., Ed.; Elsevier: Oxford, UK, 2015; Volume 2, pp. 255-261.

104. Haslam, S.A.; McMahon, C.; Cruwys, T.; Haslam, C.; Jetten, J.; Steffens, N.K. Social cure, what social cure? The propensity to underestimate the importance of social factors for health. Soc. Sci. Med. 2017, 198, 14-21. [CrossRef] [PubMed]

105. Merrill, J.M.; Laux, L.F.; Lorimor, R.; Thornby, J.I.; Vallbona, C. Authoritarianism's role in medicine. Am. J. Med. Sci. 1995, 310, 87-90. [PubMed]

106. Tsimtsiou, Z.; Kerasidou, O.; Efstathiou, N.; Papaharitou, S.; Hatzimouratidis, K.; Hatzichristou, D. Medical students' attitudes toward patient-centred care: A longitudinal survey. Med. Educ. 2007, 41, 146-153. [CrossRef] [PubMed]

107. Lavin, B.; Haug, M.; Belgrave, L.L.; Breslau, N. Change in student physicians' views on authority relationships with patients. J. Health Soc. Behav. 1987, 28, 258-272. [CrossRef] [PubMed]

108. Tamayo, C.A.; Rizkalla, M.N.; Henderson, K.K. Cognitive, Behavioral and Emotional Empathy in Pharmacy Students: Targeting Programs for Curriculum Modification. Front. Pharmacol. 2016, 7, 96. [CrossRef] [PubMed]

109. Sidanius, J.; Pratto, F. Social Dominance: An Intergroup Theory of Social Hierarchy and Oppression; Cambridge University Press: New York, NY, USA, 1999.

110. Merrill, J.M.; Camacho, Z.; Laux, L.F.; Thornby, J.I.; Vallbona, C. How medical school shapes students' orientation to patients' psychological problems. Acad. Med. 1991, 66 (Suppl. 9), S4-S6. [PubMed]

111. Guimond, S.; Dambrun, M.; Michinov, N.; Duarte, S. Does social dominance generate prejudice? Integrating individual and contextual determinants of intergroup cognitions. J. Pers. Soc. Psychol. 2003, 84, 697-721. [CrossRef] [PubMed]

112. Tan, X.; Liu, L.; Huang, Z.; Zheng, W. The dampening effect of social dominance orientation on awareness of corruption: Moral outrage as an indicator. Soc. Indic. Res. 2016, 125, 89-102. [CrossRef] 
113. Van Ryn, M.; Hardeman, R.R.; Phelan, S.M.; Burke, S.E.; Przedworski, J.; Allen, M.L.; Burgess, D.J.; Ridgeway, J.; White, R.O.; Dovidio, J.F. Psychosocial predictors of attitudes toward physician empathy in clinical encounters among 4732 1st year medical students: A report from the CHANGES study. Patient Educ. Couns. 2014, 96, 367-375. [CrossRef] [PubMed]

114. Caruso, E.M.; Vohs, K.D.; Baxter, B.; Waytz, A. Mere exposure to money increases endorsement of free-market systems and social inequality. J. Exp. Psychol. Gen. 2013, 142, 301-306. [CrossRef] [PubMed]

115. Radke, H.R.M.; Hornsey, M.J.; Sibley, C.G.; Thai, M.; Barlow, F.K. Is the racial composition of your surroundings associated with your levels of social dominance orientation? PLoS ONE 2017, 12, e0186612. [CrossRef] [PubMed]

116. Lepiece, B.; Reynaert, C.; van Meerbeeck, P.; Dory, V. Social dominance theory and medical specialty choice. Adv. Health Sci. Educ. Theory Pract. 2016, 21, 79-92. [CrossRef] [PubMed]

117. Heering, M.S.; Leone, L. Power Moderates the Effects of Social Dominance Orientation on Punishment: An Experimental Analysis. Psychol. Rep. 2018. [CrossRef] [PubMed]

118. Steven, K.; Dowell, J.; Jackson, C.; Guthrie, B. Fair access to medicine? Retrospective analysis of UK medical schools application data 2009-2012 using three measures of socioeconomic status. BMC Med. Educ. 2016, 16, 11. [CrossRef] [PubMed]

119. Houghton, F. The Prevention Paradox Mark II: An appeal for diversity in public health. J. Public Health 2016, 39, e142-e144. [CrossRef] [PubMed]

120. McFarland, S. Authoritarianism, social dominance and other roots of generalized prejudice. Pol. Psychol. 2010, 453-477. [CrossRef]

121. Sidanius, J.; Sheehy-Skeffington, J.; Cotterill, S.; Nour, K.; Carvacho, H. Social dominance theory: Explorations in the psychology of oppression. In Cambridge Handbook of the Psychology of Prejudice; Sibley, C., Barlow, F., Eds.; Cambridge University Press: Cambridge, UK, 2016; pp. 149-187.

122. Christie, R.; Geis, F.L. Studies in Machiavellianism; Academic Press: New York, NY, USA, 1970; p. 340.

123. Abell, L.; Qualter, P.; Brewer, G.; Barlow, A.; Stylianou, M.; Henzi, P.; Barrett, L. Why Machiavellianism Matters in Childhood: The Relationship Between Children's Machiavellian Traits and Their Peer Interactions in a Natural Setting. Eur. J. Psychol. 2015, 11, 484-493. [CrossRef] [PubMed]

124. Schriber, R.A.; Chung, J.M.; Sorensen, K.S.; Robins, R.W. Dispositional Contempt: A First Look at the Contemptuous Person. J. Pers. Soc. Psychol. 2016, 113, 280-309. [CrossRef] [PubMed]

125. Austin, E.J.; Farrelly, D.; Black, C.; Moore, H. Emotional intelligence, Machiavellianism and emotional manipulation: Does EI have a dark side? Pers. Individ. Differ. 2007, 43, 179-189. [CrossRef]

126. Merrill, J.M.; Camacho, Z.; Laux, L.F.; Thornby, J.I.; Vallbona, C. Machiavellianism in medical students. Am. J. Med. Sci. 1993, 305, 285-288. [CrossRef] [PubMed]

127. Merrill, J.M.; Lorimor, R.J.; Thornby, J.I.; Vallbona, C. Reliance on high technology among senior medical students. Am. J. Med. Sci. 1998, 315, 35-39. [CrossRef] [PubMed]

128. Merrill, J.M.; Camacho, Z.; Laux, L.F.; Lorimor, R.; Thornby, J.I.; Vallbona, C. Uncertainties and ambiguities: Measuring how medical students cope. Med. Educ. 1994, 28, 316-322. [CrossRef] [PubMed]

129. Schultz, P.W.; Stone, W.F.; Christie, R. Authoritarianism and mental rigidity: The Einstellung problem revisited. Personal. Soc. Psychol. Bull. 1997, 23, 3-9. [CrossRef]

130. Jost, J.T.; Glaser, J.; Kruglanski, A.W.; Sulloway, F.J. Political conservatism as motivated social cognition. Psychol. Bull. 2003, 129, 339-375. [CrossRef] [PubMed]

131. Chaitoff, A.; Sun, B.; Windover, A.; Bokar, D.; Featherall, J.; Rothberg, M.B.; Misra-Hebert, A.D. Associations Between Physician Empathy, Physician Characteristics and Standardized Measures of Patient Experience. Acad. Med. 2017, 92, 1464-1471. [CrossRef] [PubMed]

132. Damiano, R.F.; DiLalla, L.F.; Lucchetti, G.; Dorsey, J.K. Empathy in Medical Students Is Moderated by Openness to Spirituality. Teach. Learn. Med. 2017, 29, 188-195. [CrossRef] [PubMed]

133. Bertram, K.; Randazzo, J.; Alabi, N.; Levenson, J.; Doucette, J.T.; Barbosa, P. Strong correlations between empathy, emotional intelligence and personality traits among podiatric medical students: A cross-sectional study. Educ. Health 2016, 29, 186-194.

134. Snowden, D.J.; Boone, M.E. A leader's framework for decision making. A leader's framework for decision making. Harv. Bus. Rev. 2007, 85, 68-76, 149. [PubMed]

135. Osler, W. Aequanimitas. In With Other Addresses to Medical Students, Nurses and Practitioners of Medicine; The Blakiston Company: Philadelphia, PA, USA, 1932; pp. 258-259. 
136. Linden, M. Placebo: Unsolved Problems for Science and Simple Conclusions for Clinical Practice. Am. J. Psychiatry 2017, 174, 91-92. [CrossRef] [PubMed]

137. Kraft-Todd, G.T.; Reinero, D.A.; Kelley, J.M.; Heberlein, A.S.; Baer, L.; Riess, H. Empathic nonverbal behavior increases ratings of both warmth and competence in a medical context. PLoS ONE 2017, 12, e0177758. [CrossRef] [PubMed]

138. Beecker, H.K.; Altschule, M.D. Medicine at Harvard; University Press of New England: Hanover, NH, USA, 1977.

139. Henderson, L.J. Physician and patient as a social system. N. Engl. J. Med. 1935, 212, 819-823. [CrossRef]

140. Halpern, L.W. Analysis Finds About 20 Veterans Died Daily from Suicide Between 2001 and 2014. Am. J. Nurs. 2016, 116, 17. [CrossRef] [PubMed]

141. Kearney, D.J.; McManus, C.; Malte, C.A.; Martinez, M.E.; Felleman, B.; Simpson, T.L. Loving-kindness meditation and the broaden-and-build theory of positive emotions among veterans with posttraumatic stress disorder. Med. Care 2014, 52 (Suppl. 5), S32-S38. [CrossRef] [PubMed]

142. DeBeer, B.B.; Kittel, J.A.; Cook, A.; Davidson, D.; Kimbrel, N.A.; Meyer, E.C.; Gulliver, S.B.; Morissette, S.B. Predicting Suicide Risk in Trauma Exposed Veterans: The Role of Health Promoting Behaviors. PLoS ONE 2016, 11, e0167464. [CrossRef] [PubMed]

143. Caldicott, C.V. "Sweeping up after the parade": Professional, ethical and patient care implications of "turfing". Perspect. Biol. Med. 2007, 50, 136-149. [CrossRef] [PubMed]

144. Bloom, S.W. The sociology of medical education: Some comments on the state of a field. Milbank Mem. Fund Q. 1965, 43, 143-184. [CrossRef] [PubMed]

145. Gordon, L.V.; Mensh, I.N. Values of medical school students at different levels of training. J. Educ. Psychol. 1962, 53, 48-51. [CrossRef]

146. Merton, R.K.; Bloom, S.; Rogoff, N. Columbia-Pennsylvania: Studies in the sociology of medical education. J. Med. Educ. 1956, 31, 552-565. [PubMed]

147. Brosnan, C.; Turner, B.S. The struggle over medical knowledge. In Handbook of the Sociology of Medical Education; Brosnan, C., Turner, B.S., Eds.; Routledge: London, UK, 2009; pp. 1-12.

148. Brosnan, C. Pierre Bourdieu and the theory of medical education: Thinking 'relationally' about medical students and medical curricula. In Handbook of the Sociology of Medical Education; Brosnan, C., Turner, B.S., Eds.; Routledge: London, UK, 2009; pp. 51-68.

149. Gomes, A.P.; Rego, S. Pierre Bourdieu and medical education. Rev. Bras. Educ. Med. 2013, 37, $260-265$. [CrossRef]

150. Greenberg, J.; Dube, E.; Driedger, M. Vaccine Hesitancy: In Search of the Risk Communication Comfort Zone. PLoS Curr. 2017, 9. [CrossRef]

151. Nyhan, B.; Reifler, J.; Richey, S.; Freed, G.L. Effective messages in vaccine promotion: A randomized trial. Pediatrics 2014, 133, E835-E842. [CrossRef] [PubMed]

152. Engel, G. How much longer must medicine's science be bound by a seventeenth century world view? Psychother. Psychosom. 1992, 57, 3-16. [CrossRef] [PubMed]

153. Iannone, N.E.; McCarty, M.K.; Branch, S.E.; Kelly, J.R. Connecting in the Twitterverse: Using Twitter to satisfy unmet belonging needs. J. Soc. Psychol. 2017, 6, 1-5. [CrossRef] [PubMed]

154. Dawkins, R.; King, W.D.; Boateng, B.; Nichols, M.; Desselle, B.C. Pediatric Residents' Perceptions of Potential Professionalism Violations on Social Media: A US National Survey. JMIR Med. Educ. 2017, 3, E2. [CrossRef] [PubMed]

155. Koo, K.; Ficko, Z.; Gormley, E.A. Unprofessional content on Facebook accounts of US urology residency graduates. BJU Int. 2017, 119, 955-960. [CrossRef] [PubMed]

156. Song, Y.; Shi, M. Associations between empathy and big five personality traits among Chinese undergraduate medical students. PLoS ONE 2017, 12, e0171665. [CrossRef] [PubMed]

157. Costa, P.; Alves, R.; Neto, I.; Marvao, P.; Portela, M.; Costa, M.J. Associations between medical student empathy and personality: A multi-institutional study. PLOS ONE 2014, 9, e89254. [CrossRef] [PubMed]

158. Costa, P.T.; McCrae, R.R. NEO PI-R: Professional Manual; Psychological Assessment Resources: Lutz, FL, USA, 1992.

159. Wilson, C.J.; Nagy, M.S. The effects of personality on workplace bullying. Psychol. Manag. J. 2017, 20, $123-147$. [CrossRef] 
160. Jocham, A.; Kriston, L.; Berberat, P.O.; Schneider, A.; Linde, K. How do medical students engaging in elective courses on acupuncture and homeopathy differ from unselected students? A survey. BMC Complement. Altern. Med. 2017, 17, 148. [CrossRef] [PubMed]

161. Lee, K.; Ashton, M.C. Psychopathy, Machiavellianism and narcissism in the Five-Factor Model and the HEXACO model of personality structure. Personal. Indiv. Differ. 2005, 38, 1571-1582. [CrossRef]

162. Ekehammar, B.; Akrami, N.; Gylje, M.; Zakrisson, I. What matters most to prejudice: Big Five personality, Social Dominance Orientation, or Right-Wing Authoritarianism? Eur. J. Personal. 2004, 18, 463-482. [CrossRef]

163. Li, M.; Mobley, W.H.; Kelly, A. Linking personality to cultural intelligence: An interactive effect of openness and agreeableness. Personal. Indiv Differ. 2016, 89, 105-110. [CrossRef]

164. Talmor, A.G.; Falk, A.; Almog, Y. A new admission method may select applicants with a distinct personality profile. Med. Teach. 2017, 39, 646-652. [CrossRef] [PubMed]

165. Schwartz, S.H.; Cieciuch, J.; Vecchione, M.; Davidov, E.; Fischer, R.; Beierlein, C.; Ramos, A.; Verkasalo, M.; Lönnqvist, J.E.; Demirutku, K.; et al. Refining the theory of basic individual values. J. Pers. Soc. Psychol. 2012, 103, 663-688. [CrossRef] [PubMed]

166. Meadows, A.; Higgs, S.; Burke, S.E.; Dovidio, J.F.; van Ryn, M.; Phelan, S.M. Social Dominance Orientation, Dispositional Empathy and Need for Cognitive Closure Moderate the Impact of Empathy-Skills Training but Not Patient Contact, on Medical Students' Negative Attitudes toward Higher-Weight Patients. Front. Psychol. 2017, 8, 504. [CrossRef] [PubMed]

167. Daya, Z.; Hearn, J.H. Mindfulness interventions in medical education: A systematic review of their impact on medical student stress, depression, fatigue and burnout. Med. Teach. 2017, 7, 1-8. [CrossRef] [PubMed]

168. Dyrbye, L.N.; Shanafelt, T.D.; Werner, L.; Sood, A.; Satele, D.; Wolanskyj, A.P. The Impact of a Required Longitudinal Stress Management and Resilience Training Course for First-Year Medical Students. J. Gen. Intern. Med. 2017, 32, 1309-1314. [CrossRef] [PubMed]

169. Dambrun, M.; Kamiejski, R.; Haddadi, N.; Duarte, S. Why does social dominance orientation decrease with university exposure to the social sciences? The impact of institutional socialization and the mediating role of “geneticism." Eur. J. Soc. Psychol. 2009, 39, 88-100.

170. Merrill, J.M.; Laux, L.; Thornby, J.I. Troublesome aspects of the patient-physician relationship: A study of human factors. South. Med. J. 1987, 80, 1211-1215. [CrossRef] [PubMed]

171. Dubos, R. The Despairing Optimist. Am. Sch. 1977, 46, 280-288.

172. Ward Platt, M. Rudeness. Arch. Dis. Child. 2017, 102, 481. [CrossRef] [PubMed]

173. Berk, R.A. Microaggressions Trilogy: Part 1. Why do microaggressions matter? J. Fac. Dev. 2017, 31, 63-73.

174. Riskin, A.; Erez, A.; Foulk, T.A.; Riskin-Geuz, K.S.; Ziv, A.; Sela, R.; Pessach-Gelblum, L.; Bamberger, P.A. Rudeness and Medical Team Performance. Pediatrics 2017, 139. [CrossRef] [PubMed]

175. Roberts, N.K.; Dorsey, J.K.; Wold, B. Unprofessional behavior by specialty: A qualitative analysis of six years of student perceptions of medical school faculty. Med. Teach. 2014, 36, 621-625. [CrossRef] [PubMed]

176. Bradley, V.; Liddle, S.; Shaw, R.; Savage, E.; Rabbitts, R.; Trim, C.; Lasoye, T.A.; Whitelaw, B.C. Sticks and stones: Investigating rude, dismissive and aggressive communication between doctors. Clin. Med. 2015, 15, 541-545. [CrossRef] [PubMed]

177. Baker, M.; Wessely, S.; Openshaw, D. Not such friendly banter? GPs and psychiatrists against the systematic denigration of their specialties. Br. J. Gen. Pract. 2016, 66, 508-509. [CrossRef] [PubMed]

178. Vogel, L. Doctors dissect medicine's bullying problem. CMAJ Can. Med. Assoc. J. 2017, 189, E1161-E1162. [CrossRef] [PubMed]

179. Valentine, S.; Fleischman, G. From schoolyard to workplace: The impact of bullying on sales and business employees' Machiavellianism, job satisfaction and perceived importance of an ethical issue. Hum. Resour. Manag. 2017, 1-13. [CrossRef]

180. Barrett, J.; Scott, K.M. Acknowledging medical students' reports of intimidation and humiliation by their teachers in hospitals. J. Paediatr. Child Health 2018, 54, 69-73. [CrossRef] [PubMed]

181. Scott, K.M.; Caldwell, P.H.; Barnes, E.H.; Barrett, J. “Teaching by humiliation” and mistreatment of medical students in clinical rotations: A pilot study. Med. J. Aust. 2015, 203, E185. [CrossRef] [PubMed]

182. Isaacs, D. From humiliation to humility. J. Paediatr. Child Health 2018, 54, 5-6. [CrossRef] [PubMed]

183. Albanese, M.A.; Snow, M.H.; Skochelak, S.E.; Huggett, K.N.; Farrell, P.M. Assessing personal qualities in medical school admissions. Acad. Med. 2003, 78, 313-321. [CrossRef] [PubMed] 
184. Bensch, D.; Paulhus, D.L.; Stankov, L.; Ziegler, M. Teasing Apart Overclaiming, Overconfidence and Socially Desirable Responding. Assessment 2017. [CrossRef] [PubMed]

185. Tracey, T.J. A note on socially desirable responding. J. Couns. Psychol. 2016, 63, 224-232. [CrossRef] [PubMed]

186. Racine, A.D. Providers and patients face-to-face: What is the time? Isr. J. Health Policy Res. 2017, 6, 54. [CrossRef] [PubMed]

187. Ahern, A.L.; Wheeler, G.M.; Aveyard, P.; Boyland, E.J.; Halford, J.C.G.; Mander, A.P.; Woolston, J.; Thomson, A.M.; Tsiountsioura, M.; Cole, D.; et al. Extended and standard duration weight-loss programme referrals for adults in primary care (WRAP): A randomised controlled trial. Lancet 2017, 389, 2214-2225. [CrossRef]

188. Strasser, R.; Worley, P.; Cristobal, F.; Marsh, D.C.; Berry, S.; Strasser, S.; Ellaway, R. Putting communities in the driver's seat: The realities of community-engaged medical education. Acad. Med. 2015, 90, 1466-1470. [CrossRef] [PubMed]

189. Habitus. Routledge Social Theory Re-Wired. Writing Out Loud. Available online: http:/ / routledgesoc.com/ category/profile-tags/habitus (accessed on 22 February 2018).

190. Saher, M.; Lindeman, M. Alternative medicine: A psychological perspective. Pers. Indiv. Differ. 2005, 39, 1169-1178. [CrossRef]

191. Moodie, A.R. What Public Health Practitioners Need to Know About Unhealthy Industry Tactics. Am. J. Public Health 2017, 107, 1047-1049. [CrossRef] [PubMed]

192. Clapp, J.; Scrinis, G. Big food, nutritionism and corporate power. Globalizations 2017, 14, 578-595. [CrossRef]

193. Leon, K.S.; Ken, I. Food Fraud and the Partnership for a 'Healthier' America: A Case Study in State-Corporate Crime. Crit. Crim. 2017, in press. [CrossRef]

194. The Carnegie Foundation. The Carnegie Foundation Report. Med. Stand. St. Louis Med. Rev. 1910, 59, 215-216.

195. Lee, V. Transparency and Trust-Online Patient Reviews of Physicians. N. Engl. J. Med. 2017, 376, 197-199. [CrossRef] [PubMed]

(C) 2018 by the authors. Licensee MDPI, Basel, Switzerland. This article is an open access article distributed under the terms and conditions of the Creative Commons Attribution (CC BY) license (http://creativecommons.org/licenses/by/4.0/). 